Discussion

Papers
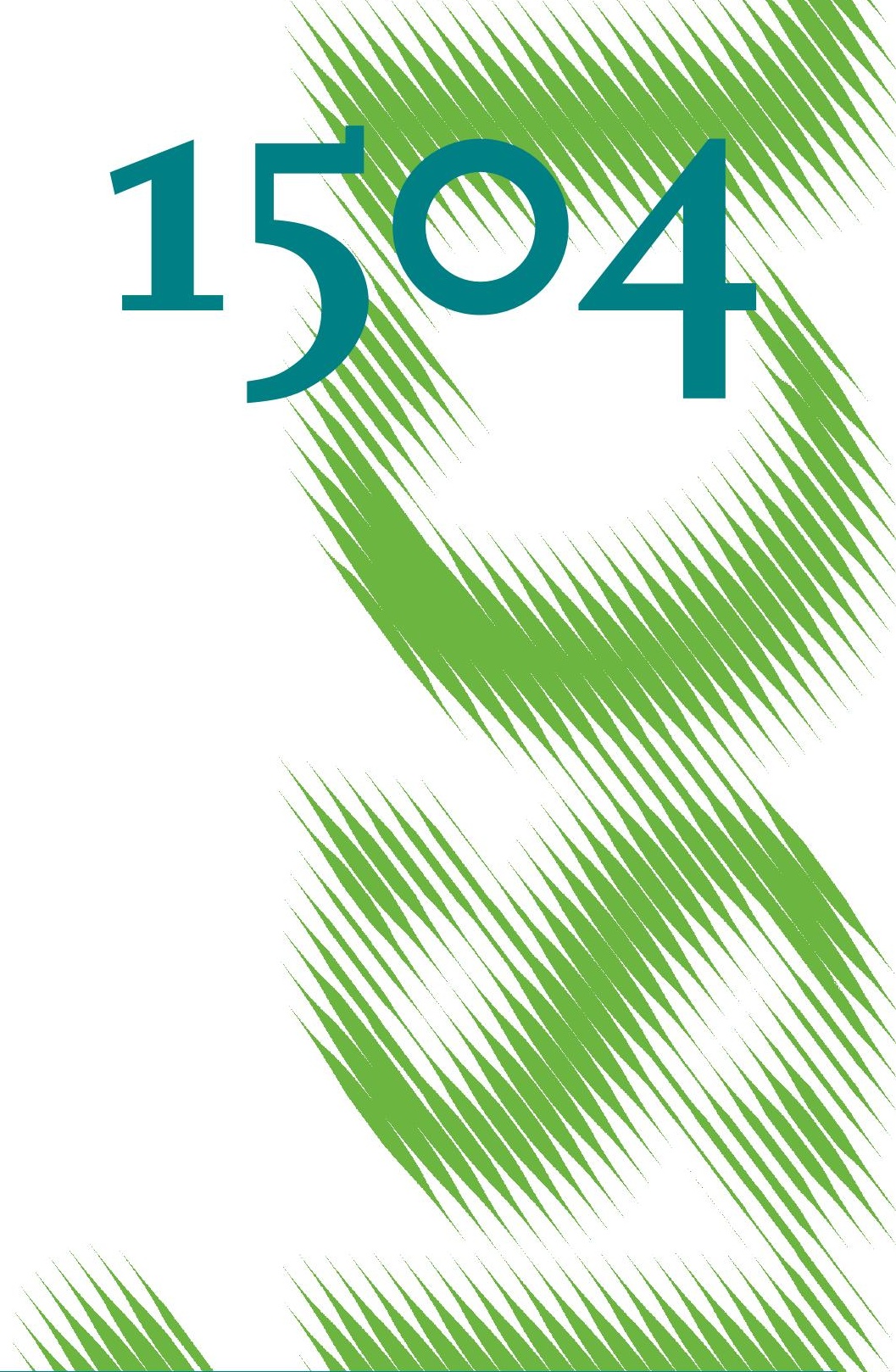

Childhood Roots of Financial

Literacy 
Opinions expressed in this paper are those of the author(s) and do not necessarily reflect views of the institute.

IMPRESSUM

(C) DIW Berlin, 2015

DIW Berlin

German Institute for Economic Research

Mohrenstr. 58

10117 Berlin

Tel. +49 (30) $89789-0$

Fax +49 (30) $89789-200$

http://www.diw.de

ISSN electronic edition 1619-4535

Papers can be downloaded free of charge from the DIW Berlin website:

http://www.diw.de/discussionpapers

Discussion Papers of DIW Berlin are indexed in RePEc and SSRN:

http://ideas.repec.org/s/diw/diwwpp.html

http://www.ssrn.com/link/DIW-Berlin-German-Inst-Econ-Res.html 


\title{
Childhood Roots of Financial Literacy
}

\author{
Antonia Grohmann ${ }^{a}$, Roy Kouwenberg ${ }^{b, c}$ and Lukas Menkhoff ${ }^{a, d, e, ~ * ~}$
}

August 31, 2015

\begin{abstract}
Financial literacy predicts informed financial decisions, but what explains financial literacy? We use the concept of financial socialization and aim to represent three major agents of financial socialization: family, school and work. Thus we compile twelve relevant childhood characteristics in a new survey study and examine their relation to financial literacy, while controlling for established socio-demographic characteristics. We find in a mediation analysis that both family and school positively affect the financial literacy of adults. Moreover, financial literacy and school related variables also have a direct effect on financial behavior. This suggests that family factors and schooling work through complementary channels.
\end{abstract}

JEL-Classification: D14, G11, 120

Keywords: Financial literacy, financial behavior, family background, education, numeracy

\footnotetext{
${ }^{a}$ German Institute for Economic Research (DIW Berlin), 10108 Berlin, Germany.

${ }^{b}$ Mahidol University, College of Management, 69 Vipawadee Rangsit Road Samsennai, Phayathai District, Bangkok 10400, Thailand.

c Erasmus University Rotterdam, School of Economics, 6032 PA Rotterdam, The Netherlands.

${ }^{d}$ Humboldt-University Berlin, Department of Economics, 10178 Berlin, Germany.

e Leibniz University Hannover, 30167 Hannover, Germany.

* corresponding author, phone: ++49 (0)30 89789435

Email addresses: grohmann@glad.uni-hannover.de, (A. Grohmann), roy.kou@mahidol.ac.th (R. Kouwenberg), menkhoff@gif.uni-hannover.de (L. Menkhoff)
} 


\section{Childhood Roots of Financial Literacy}

\section{Introduction}

Many economic decisions require basic knowledge of financial concepts, such as interest rates and inflation. However, many people lack this type of knowledge. The degree of this deficiency has been systematically researched using tests, which collect "financial literacy" scores. There is growing evidence that individuals who possess higher financial literacy have better economic outcomes as it improves financial decision making (e.g., Lusardi and Mitchell, 2014). At the same time, these studies also find that in many countries and many population groups, financial literacy levels are low. In the USA only $30.2 \%$ can answer all three of the standard financial literacy questions. This number is not much higher at $44.8 \%$ and 53.2\% in the Netherlands and Germany respectively (Lusardi and Mitchell, 2014, BucherKoenen and Lusardi, 2011, van Rooij et al., 2011b). For the middle class sample used in this study only $17.3 \%$ of respondents can answer three similar questions correctly. Financial literacy is therefore important for personal welfare and at the same time too low for many people. However, whereas the impacts of financial literacy have been frequently examined, what remains much less clear is: where does financial literacy come from?

Several variables have been found to be linked to a person's financial literacy. These factors include socio-demographic variables in the way that better education, higher age or higher incomes are related to higher financial literacy. Many of these factors seem to be at least partially shaped by childhood experiences of today's adults (see Lusardi et al., 2010). Indeed, several studies either look at the impact of some childhood experiences on financial behavior (e.g., Webley and Nyhus, 2013, Bucciol and Veronesi, 2014), or use a specific childhood variable as instrument for financial literacy (Behrman et al., 2010, 2012, van Rooij et al., 2011b). Thus many childhood variables have been considered in relation to financial literacy and financial behavior. What remains less clear is: what are the main channels through which childhood experiences affects financial literacy and financial behavior?

We contribute to filling this gap in the literature by combining two major strands in the literature. First, "financial socialization" studies have examined the role of childhood experiences in shaping financial knowledge and behavior (Webley and Nyhus, 2006, 2013; Shim et al., 2009, 2010). Second, “financial literacy” studies have shown in great detail the impact of financial literacy on financial behavior (see, e.g., Lusardi and Mitchell, 2014). Here we try to bridge this gap and implement a mediation analysis, linking childhood variables to 
financial behavior through financial literacy as a mediator. Our set of childhood experiences is motivated by the literature. In order to reveal the most important childhood factors, we perform a factor analysis and group twelve childhood variables together into five scales: parental education (as a major aspect of family background), financial socialization by parents, economics at school, educational quality and financial socialization through experience with money and work. These five scales nicely represent the three main socialization agents used for example by Shim et al. (2009, 2010), that is, family, school and work.

Following the literature, we expect that all five childhood scales are positively related to the financial literacy of adults. Earlier empirical work by Shim et al. $(2009,2010)$ showed that among the main financial socialization channels (parents, school and work), parental teaching has by far the largest impact on financial knowledge. Our relative contribution is that whereas Shim et al. (2009, 2010) studied college students and included subjective (self-reported) measures of financial knowledge, we study a sample of adults and we use established measures of financial knowledge from the financial literacy literature. In addition, we control for the effects of basic mathematical skills (numeracy). In particular, schooling may improve numeracy which in turn is an important skill supporting financial literacy. We thus test whether numeracy is a mediator in the relationship between childhood factors and financial literacy.

In regards to financial behavior, we take diversification of financial assets as our main outcome variable, representing good financial decision making. The majority of respondents in our sample only hold savings accounts (48\%), which tend to offer negative real returns after taking inflation into account. Investing in other financial assets, such as fixed deposits, bonds and stocks, can offer higher expected returns, while spreading savings over multiple asset types can help reduce risk. We expect that higher financial literacy is associated with better diversification of financial assets. Further, we test whether the childhood scales have a direct effect on this financial behavior, beyond their indirect effect through financial literacy. Here we extend the work of Webley and Nyhus (2006, 2013) and Bucciol and Veronesi (2014) who document a positive direct effect of parental teaching on savings, but without considering the role of financial literacy as a potential mediator.

For this research we require a wealth of specific information, on childhood experiences, financial literacy, as well as financial outcomes, which is not available - to the best of our knowledge - in any existing dataset. Therefore, we had to compile a new questionnaire which is specifically designed for our research purpose, although we rely on standard items whenever 
possible. We survey more than 500 people from a broadly defined middle class in Bangkok, Thailand.

The choice of middle class people in Thailand has some advantages: (i) It selects respondents whose financial decisions involve a lot of potential variety, different to decisions of the poor (Xu and Zia, 2012). (ii) Respondents have a meaningful education allowing us to study its potential impact on financial literacy. (iii) The survey in an emerging economy brings a fast changing environment where financial literacy is particularly important as argued by Campbell (2006) (also Klapper et al., 2013). (iv) The focus on the middle class ensures that the survey can be compared to most studies from advanced economies where the global middle class, as it is defined by the OECD (Kharas, 2010, Kharas and Gertz, 2010), dominates the population.

Our main finding is that we reveal two channels by which childhood experiences explain adults' degree of financial literacy: financial socialization by parents and the schooling channel. Financial socialization by parents has a significant positive influence on the financial literacy of their adult children. Having had parents who taught how to budget and encouraged saving, improves the degree of financial literacy by about $14 \%$. Better financial literacy in turn is positively related to better financial decision making (asset diversification).

The second channel by which childhood experiences explain financial literacy is schooling. Here the impact on financial literacy is indirect as better education at school is linked to better numeracy, which in turn improves financial literacy. At the same time, the two schooling factors that we consider in our study also have a direct effect on good financial decision making. It may be reassuring to see that schooling helps in becoming capable of good financial decision making, although its effect on financial literacy is indirect.

Our research is clearly linked to the rapidly growing literature on financial literacy. Although we compile a new sample, we can safely reproduce stylized facts regarding relations between socio-demographic characteristics and financial literacy documented in Lusardi and Mitchell (2014). Moreover, in independent work, Grohmann et al. (2014) have replicated standard economics analyses with our data showing the impact of financial literacy on financial behavior. All this indicates that our new investigations about the influence of childhood experiences on financial literacy and financial behavior have meaning beyond our particular dataset.

This study is organized in six sections following the introduction. Section 2 shortly derives hypotheses from the literature on childhood and financial behavior, Section 3 introduces the underlying dataset. In Section 4 we show descriptive statistics of the potential 
childhood roots of financial literacy. Section 5 gives the main results of our empirical research on the roots of financial literacy and Section 6 documents robustness tests. Section 7 concludes.

\section{Background and literature review}

In this section we link our research to earlier works in order to derive testable hypotheses. Basically we follow Shim et al. (2009, 2010, 2015) and others in their distinction of three crucial socialization agents: family, school and work. Going further, we split up family and school so that we analyze five groups of childhood roots (Sections 2.2 to 2.6). Although our focus is on these roots' impact on financial literacy, we also consider "numeracy" besides "financial literacy" as another mediator variable influencing financial behavior.

\subsection{Financial literacy, personality and society}

Despite plenty of evidence on the link between financial literacy and good financial decision making (Lusardi and Mitchell et al., 2014), results based on evaluations of financial literacy trainings have been mixed at best. Studies have found that there is often no significant effect on financial literacy or financial behavior. If such an effect is found, it tends to disappear with time (Fernandes et al., 2014, Bruhn et al., 2014). This almost automatically leads to the question where does financial literacy come from and why is financial behavior so hard to influence.

A number of studies link financial literacy with different aspects of personality such as self-control or (low) time preference (Gathergood, 2012, Dick and Jarozek, 2013, Meier and Sprenger, 2013, Fernandes et al., 2014). At the same time there is evidence that financial socialization by the society that one lives in is linked to financial literacy. Bucher-Koenen and Lamla (2014) show that financial literacy is lower is East than in West Germany, even twenty years after unification. Jappelli (2010) shows that financial literacy is linked to the social security system that operates in a country; financial literacy tends to be higher in countries with less generous social security systems. This indicates that financial literacy and especially financial behavior is also deeply rooted in personal or societal circumstances and hence not easily influenced by short-term trainings.

In this paper we aim to explore this further and hence study the childhood of today's adults. We here bridge a gap between the financial literacy literature often studied as part of economics and the literature on financial socialization, which is often discussed as part of 
psychology. Financial socialization goes further than simply focusing on an improvement in financial knowledge, as it also analyzes the process by which attitudes and values are formed that may influence financial knowledge and especially financial decision making. Financial socialization is considered a lifelong process, but the early years are of particular importance (Moschis, 1985).

The literature on financial socialization distinguishes between three or four socialization agents through which socialization takes place: family or parents, school, experiences at work and the media (Gudmunson and Danes, 2011). We here focus on the first three of these four socialization agents along the line of Shim et al. (2009, 2010, 2015). Exposure to the media is considerably harder to measure and also should be very similar within our rather homogenous group of respondents. We measure the effect of the family and of school in two different ways and the effect of work and early experiences with money using a single scale.

A framework for the expected effect of each of the socialization agents is developed below. In addition to the effect of the childhood factors on financial literacy, we also investigate their effect on numeracy as another potential mediator, and the direct effect of the childhood factors on financial behavior as the final outcome. The hypothesized relationships between financial socialization agents, financial literacy, numeracy and financial behavior - as derived from the literature - are summarized in Figure 1, and explained in more detail below. Therefore, this figure does not show the empirical relations we find in the analysis of our data, although the main structure will be confirmed.

\subsection{Family background}

First we study family background, which will later be narrowed to the highest educational attainment of the mother and of the father. Family background and education of the parents have been linked to a large number of educational attainments, as well as better lifetime outcomes such as higher lifetime earnings. Carneiro et al. (2013) and Heckman (2006) show, that higher maternal education has an influence on cognitive achievement and behavior during childhood. More broadly, Cameron and Heckman (2001) link parental income during adolescence to educational attainment. Cunha and Heckman (2007) develop a theoretical model that shows the link between family background, i.e. parents' education, and cognitive ability as well as later life outcomes.

Variables related to financial decision making and risk attitudes have also been related to parents' education and family background. Studies show that better education of parents leads to higher risk tolerance after a change of compulsory schooling laws that increased parents' 
education (Hryshko et al., 2011). Similarly, Dohmen et al. (2012) find that attitudes such as risk and trust are transmitted from parents to children. Cesarini et al. (2010) explain about 25\% of risk taking in financial decision making by genetic variation. Sometimes, parental education is not considered as being directly part of financial socialization, but studies separate the effect of intentional teaching by parents and the general effect that parents' characteristics have on their children (Gudmunson and Danes, 2011).

From these studies we can see that parental education can have an effect on both more knowledge based factors, as well as certain behaviors. We hence propose that children of better educated parents will have higher financial literacy and may also make better financial decisions.

\subsection{Financial socialization by parents}

Parents also actively influence their children to make better decisions and learn about finance by trying to install good behavior in their children. The importance of financial teaching and parental communication is well established in the financial socialization literature. Several studies show that the effect of family is far stronger than financial socialization through any other socialization agent. Many of these studies, however, focus on the effect of parental teaching on teenagers or young adults, and thus do not observe their behavior later in life.

Shim et al. (2009, 2010) find that parental teaching has a stronger influence on the financial knowledge of first year college students than financial education in high school and early experience with money. Focusing on financial behavior, Webley and Nyhus (2006, 2013) show that parental teaching, such as encouraging children to save and teaching budgeting, has a positive effect on future orientation and savings rates of young adults from age 18 to 32. Looking at parenting more broadly, Nyhus and Webley (2013) find that parenting style has an important influence on the economic orientation of children. Kim et al. (2015) find that parental teaching practices, such as shopping with children and discussing finances, mediate parenting styles (the way that parents raise their children) and so influence economic socialization.

Few studies explicitly analyze the effect of parental teaching on adults. Bucciol and Veronesi (2014) stand out here and find that any form of parental teaching received in childhood (self-reported and recollected) has a positive effect on the savings behavior of adults (from 18 to 80 years old). They conclude that when it comes to different parental teaching strategies: "the more the better". Further, Hira et al. (2013) establish that financial 
socialization by the parents is positively associated with household net wealth and the tendency to invest regularly.

In summary, this literature shows that active financial socialization by the family has an influence on good financial behavior. However, the link from financial socialization to financial literacy is less established, partly because financial literacy is typically measured in the economic literature. Two open issues, hence, remain: first, the vast majority of studies still focus on the effect of family financial socialization on adolescents and young adults; thus it is not obvious that this effect still holds in adulthood. Second, it seems plausible that financial literacy is a channel through which financial socialization by parents leads to better financial behavior; thus we hypothesize that parental teaching leads to better financial literacy.

\subsection{Economics at school}

Teaching economics at school seems like the obvious choice when it comes to an easy way to increase financial literacy and induce good financial behavior. Indeed, Bernheim et al. (2001) use variation in the introduction of consumer education across states in the U.S. to show that these programs had a positive effect on asset accumulation later in life. However, exploiting the same variation in financial education between states, but with more data and a different model specification, Cole and Shastry (2009) find no effect of financial education on financial market participation. Similarly, Christiansen et al. (2008) show that economists are more likely to hold stocks.

On the other hand, Carlin and Robinson (2012) find in a hypothetical decision making scenario that students who received financial education at school tend to make better decisions. In addition and reassuringly, Shim et al. $(2009,2010)$ reveal a positive link between high school financial education and financial knowledge. This effect is weaker than that of parental teaching. It has to be noted here that Shim et al.’s measure of financial knowledge includes objective as well as subjective (self-reported) measures of financial knowledge.

We can see here that evidence of the effect of economics at school on financial decisions and financial knowledge is mixed. Moreover, the evidence so far is mostly limited to studies conducted in the U.S. We will here test the hypothesis that having had economics as a subject at school has a positive effect on financial literacy and numeracy, as well as financial behavior.

\subsection{Educational quality}


Although the relationship between years of education and financial literacy has been well established in the literature (Lusardi and Mitchell, 2007), little attention has been paid to the effects of educational quality and content on financial literacy. Herde et al. (2012) find that having taken more math related classes and academic performance in general is associated with higher knowledge of one's own financial situation; however, this relationship is strongest for those without college education.

Educational quality has become an important issue in many middle income and developing countries. Heynemen and Loxley (1983) show that educational quality has a significant positive effect on student achievement, especially in low income countries. Considering educational quality more broadly, it has been well established that educational quality has an important effect on returns to education (see Psacharopolus and Patrinos, 2004, for example).

Although the detailed effect of higher educational quality on financial literacy (or related outcomes), to the best of our knowledge, has hardly been studied, we hypothesize that those who experienced a higher quality education would be more financially literate and show better numeracy skills. We here do not assume that higher educational quality has an effect on financial decision making directly.

\subsection{Financial socialization through experience with work and money}

Shim et al. (2009) find that work experience during high school is linked to better financial knowledge, however, as mentioned above this effect is smaller than that of parental teaching or financial education at school. Also Loible et al. (2011) argue that savings habits play an important role in savings behavior. As many habits later in life are formed during childhood, this indicates that childhood experiences with money will have an important influence on financial decision making and possibly on financial literacy.

Different from this, Webley and Nyhus (2013) find that doing chores for money and having a job as an adolescent is linked to having less intention to save in the next year, and that working as an adolescent is predictive of holding high levels of debt later on in life.

Here again, the evidence does not provide a very clear picture. We therefore study the effect of early experiences with money further. We hypothesize that there is a link between socialization through early experience with money and financial literacy, as well as financial behavior.

\subsection{The effect of numeracy}


Finally, it seems obvious that financial literacy and numeracy are highly correlated. Those with higher numeracy, hence, also tend to have higher financial literacy (Cole et al., 2011). The link between cognitive ability and financial decision making has also been established in the literature (Agarwal and Mazumder, 2013). The childhood factors described above may also influence numeracy and cognitive ability as well as, or instead of, financial literacy. This is especially true for the education based factors, as their influence is likely to be broader than just influencing financial literacy. We therefore regard numeracy basically as an outcome of schooling efforts and test whether childhood factors have an effect on numeracy, and whether numeracy mediates financial literacy.

\section{Data}

Section 3.1 describes the conduct of the survey and descriptive statistics about sociodemographic variables used. Section 3.2 introduces our measure of financial literacy and Section 3.3 reports the relations between socio-demographic variables, financial literacy and numeracy. The impact of financial literacy on financial decisions is then sketched in Section 3.4 .

\subsection{The survey data}

We collect data in Bangkok, the capital of Thailand, an 'upper-middle income' country with GDP per capita of 5,480 US-Dollar (USD) in 2012. In Thailand a large middle class with significant financial needs and wealth has developed. This group is largely concentrated in the larger Bangkok area, a megacity with 15 million inhabitants, producing $44 \%$ of the country's GDP. Corrected for purchasing power, the GDP per capita level in Bangkok is similar to countries like Greece and the Czech Republic. ${ }^{1}$ Further, the consumer finance services available to our middle class target group in Bangkok are well developed, similar to high income countries.

The data underlying this research was collected in face-to-face street interviews throughout Bangkok in December 2012. In preparation for these interviews a questionnaire was developed by the authors of this paper and a test run was conducted using participants similar to the sample group. The survey was conducted by a Bangkok-based market research firm, who trained teams of interviewers for our specific questionnaire. Survey teams approached individuals at 28 different locations in Bangkok and at several different times of

\footnotetext{
${ }^{1}$ When considering GDP per capita in nominal USD, without correcting for purchasing power effects, Bangkok’s larger area GDP per capita in 2012 is similar to Turkey, Malaysia and Brazil.
} 
the day, in order to get a representative mixture of respondents, with all locations and times decided on before the start of the survey.

The target group, middle class people in Bangkok, was stratified along four criteria: The interviewer teams aim for a balanced sample regarding: (1) gender, (2) the age of participants has to be between 18 and 60 years, (3) people have to be responsible for their own or their household's financial affairs, and (4) participants have to earn at least 15,000 Baht per month (460 USD). This income level is chosen because it represents the minimum salary for an employee with a bachelor degree as determined by law. Fulfillment of these criteria was checked before the main survey using preliminary questions. The most common reason why people were not included was low income. Overall, about 30\% of people approached could not be included into the sample. The selection process obviously has an effect on the composition of the sample (see Table 1): the mean monthly individual income is about 840 US Dollar (27,000 Baht), which is $60 \%$ higher than the average income for employees in Bangkok. It follows that the large majority of our sample can be defined as belonging to the global middle class as defined in OECD studies (Kharas, 2010, Khara and Gertz, 2010). Hence, as intended, our survey excludes the urban poor who have completely different financial needs and constraints. Table 1 further shows that $48 \%$ of the respondents are women. The mean age is slightly below 35 years, with a standard deviation of 9.5 years.

Beyond this we collect the following information, also provided in Table 1: the mean monthly household income is 2,010 US-Dollar (64,000 Baht). On average each household has 2.5 earners, 3 adults live in the household, there are 0.8 children living in the household and $46 \%$ of respondents are married. The educational level is high by Thai standards, as $64 \%$ have a bachelor degree. Less than 5\% have only visited primary school, $28 \%$ have finished secondary school or a vocational education, and 3\% have a master degree.

We ask participants to respond to a simple lottery question to measure their attitude towards risk, adapted from Barsky et al. (1997): “Imagine you just won 100,000 Baht in a lottery and you can invest this money in a business. It is equally likely that the business goes well or not. If it goes well you can double the amount invested after one year. If it does not go well you can lose half the amount you invested. What fraction of the 100,000 would you invest in the business?”2 In order to ease the interpretation of the risk aversion measure, the

\footnotetext{
${ }^{2}$ Barsky et al. (1997) implemented this risk aversion question as part of the Health and Retirement Study survey in the U.S. This measure has previously been used, for example, by Dohmen et al. (2011) and Hardeweg et al. (2013), for explaining behavior. These papers have shown that it is consistently related to an experimental measure of risk attitude which is based on the Holt and Laury (2002)procedure.
} 
answers have been reversed and rescaled from 0 to 1 , so that 1 represents someone unwilling to take risk. The mean value is 0.49 , slightly leaning towards risk taking preferences.

Finally, it is to be expected that financial literacy is related to numeracy skills. In order to measure numeracy, we ask four questions taken from Cole et al. (2011). The percentage of people answering each individual question correctly varies between $83 \%$ and $95 \%$, and the average is 3.56 out of 4 (details in Table A1). The coefficient of rank correlation between numeracy and financial literacy is highly significant, but its value of 0.25 confirms that the two measures capture different skills.

\subsection{The degree of financial literacy}

We base our research on the use of a slightly extended version of the standard Lusardi and Mitchell (2014) financial literacy score. The Lusardi-Mitchell score is probably the most commonly used measure of financial literacy. It is based on the answers to three questions, measuring understanding of three basic financial concepts, that is, interest rates, inflation and diversification. ${ }^{3}$ In line with other studies, we award one point for each correct answer. Hence the resulting score lies between 0 and 3 .

In addition to these three items, we ask respondents a fourth question: to name foreign banks operating in Thailand, which we take as an indicator of institutional knowledge. The standard Lusardi-Mitchell questions have been subject to criticism for being too focused on numeracy skills (Carpena et al., 2011). There are ten foreign banks operating in the retail market in Bangkok. Respondents can name up to four foreign banks. Thus by awarding 0.25 points per named foreign bank, we construct a fourth financial literacy item, being scaled between 0 for not knowing any foreign bank operating in Thailand and 1 for knowing at least four foreign banks. Adding this 0-1 scale to the score for the three standard Lusardi-Mitchell items generates our measure of financial literacy, which varies between 0 and 4 and increases in steps of 0.25 .

Responses to the financial literacy questions in our sample population are presented in Table 2. Question 1 on interest rate appears to be the easiest to answer, where $79 \%$ answer correctly. With 62\%, fewer answer the inflation question correctly. In contrast, the question on diversification seems to be difficult as only $24 \%$ give the correct answer. This poor outcome can be explained by the fact that only $8 \%$ of our middle class sample holds stocks or equity funds themselves. Finally, the mean score for naming foreign banks is 0.56, meaning that

\footnotetext{
${ }^{3}$ For the interest rate question we follow Cole et al. (2011), who suggest a minor adjustment of the original question.
} 
people know on average two foreign banks. In total, the mean score of our 4-item measure is 2.21 .

The full distribution of financial literacy scores is shown in Figure 2, where we also show the result for the 3-item Lusardi-Mitchell score. There is not much difference between both measures but our 4-item score has more variation which may contribute to somewhat larger R-squares in later regressions (see robustness section). When we compare these results to earlier studies relying on the Lusardi-Mitchell score (see e.g. Xu and Zia, 2012) we find that the degree of financial literacy is similar to many developed countries. At the same time it is much higher than, for example, in rural India (Cole et al., 2011).

\subsection{Relations of socio-demographic variables with financial literacy and numeracy}

We find some common patterns as a higher degree of financial literacy is positively related to higher education, higher income and also lower risk aversion. These results provide information about possibly relevant covariates of financial literacy (see details in Table A2).

Results for numeracy look similar; higher numeracy is associated with higher income and higher education. Similarly, numeracy seems to be higher for those with lower risk aversion, and we also find a negative relationship between age and numeracy.

\subsection{The impact of financial literacy on financial decisions}

Any analysis of the determinants of financial literacy necessarily requires that the specific measure of financial literacy indeed predicts financial behavior, to be meaningful and useful. Earlier studies have shown that financial literacy has a positive effect on long-term savings and retirement planning (Lusardi and Mitchell, 2007, Clark et al., 2012), stock market participation (van Rooij et al., 2011a), portfolio diversification (Guiso and Jappelli, 2008), wealth (Gustman et al., 2012, van Rooij et al. 2012, Jappelli and Padula, 2013), and informed use of debt (Lusardi and Tufano, 2009, Stango and Zinman, 2009). Results in Section 5 and 6 show that in our dataset financial literacy predicts portfolio diversification, stock market participation and ownership of fixed deposits. Grohmann et al. (2014) use the same dataset as in this paper to show that higher financial literacy is associated with better financial decisions, but without considering the influence of childhood roots and their impact on financial literacy as we do here. 


\section{$4 \quad$ Measuring childhood determinants of financial literacy}

We here discuss how each of the different childhood factors that we introduced in Section 2 are measured. The relevant survey questions and descriptive statistics are displayed in Table 3, together with the original study that each of the questions was previously used in (the source).

Family background. The first persons to influence a child are the parents, which is why we include the maternal and paternal education level as potential determinants of financial literacy. Moreover, we ask respondents to rate the financial understanding of their parents and whether they consider their economic background when growing up to be poor. We expect that having parents with higher education and better financial understanding improves financial literacy, whereas tentatively a poor economic background may hinder development of financial literacy. Descriptive statistics of these and further childhood variables are provided in Table 3. In stark contrast to the respondents themselves, their parents have comparatively poor education considering that only $28 \%$ of fathers and $22 \%$ of mothers received at least vocational training which we take as the minimum to be classified as better education. Seen from this perspective, it seems plausible that a remarkable $28 \%$ of respondents regard their economic background as poor. Interestingly, the assessment of parents' financial understanding on a scale from 1 to 6 , representing "very bad" to "very good" is assessed rather positively with a mean of 4.4 .

Financial socialization by parents. Another important aspect of family background is whether the parents directly stimulated or instructed their children to learn about money, saving and other financial matters. We proxy such "parental teaching” by two items: (1) whether as a child's parents taught them how to budget and, (2) whether the parents encouraged savings. Table 3 shows that $83 \%$ of the respondents in our sample were taught how to budget as a child, and $86 \%$ of parents encouraged savings. We expect both items to positively predict financial literacy.

Economics at school. Taking economics as a school subject in particular, may support better understanding of financial affairs. We ask respondents whether they took economics as a subject at school. We see in Table 3 that two thirds of our sample had economics as a subject at school.

Educational quality. We ask whether the respondent was born in Bangkok. We use this variable as a proxy for having received better basic education, as schools in Bangkok tend to be of higher quality than those in rural areas. Along the same lines, completion of the highest educational degree in Bangkok may provide further information about having had a relatively 
good higher education. In our sample 64\% were born in Bangkok and 87\% received their highest degree in Bangkok.

Financial socialization through work and money. We here ask if respondents had an allowance as a child, whether they had a job before the age of 15 and if they have had a bank account before turning 18 . Remarkably, more than $99 \%$ of respondents in our sample had an allowance as a child. This high proportion may be due to the ex ante sample selection, in particular the minimum income of 15,000 Baht, which largely excludes the poorest parts of the population. As a consequence, we have to drop this item from our further analysis because there is hardly any variation in responses. Moreover, 57\% of respondents say that they had a bank account before 18. About half of the participants (47\%) answer having had a job before the age of 15. In most cases this was not a full-time job, because most of the respondents are college educated.

Correlations. Before our multivariate analysis of the determinants of financial literacy, we briefly inspect simple correlations of the childhood experience variables with our financial literacy measure, as shown in Table 3. We see that most childhood variables have a significant positive relation with financial literacy, especially mother's education, financial understanding of parents, parental teaching of finance and education at school. Exceptions are the father's education, having a poor economic background and indicators for early experiences with money. Somewhat surprisingly, having had a bank account before 18 is negatively correlated with financial literacy. Having a bank account early in life (different from job before age 15) may signal a more comfortable upbringing.

\section{Determinants of financial literacy and financial decision making}

Next we examine the impact of childhood variables on financial literacy and also on a relevant financial behavior, such as diversification of assets. In order to get a parsimonious structure of potential influences, we first reduce the number of childhood variables by a factor analysis (Section 5.1). The resulting measurement scales are the input variables for a mediation analysis, where financial literacy and numeracy serve as potential mediators of the relation between childhood factors (Section 5.2) and our main financial behavior variable (Section 5.3).

\subsection{Childhood variables: factor analysis and measurement scales}

A factor analysis of the childhood variables using the principal components method reveals that there are four factors with eigenvalue larger than one. Table 4 shows the factor 
loadings after rotation. ${ }^{4}$ The first factor has high positive loadings (>0.7) on parents encouraged savings, parents taught to budget, having had economics in school and financial understanding of the parents. Clearly, the first factor captures financial socialization through parental teaching and education at school. The second factor has strong positive loadings (> 0.8) on the father's and mother's education, and a small negative loading on "considers economic background to be boor". Factor two represents family socio-economic background. Factor three has high loadings ( $>0.8$ ) on being born in Bangkok and having completed the highest educational degree in Bangkok, both of which we consider as proxies for the quality of the respondent's education. Finally, factor four has significant loadings on having a job before the age of 15 and having a bank account before the age of 18. We interpret factor four as financial socialization through work and experience with money.

We now use the information gained from the factor analysis to create scales for the agents of financial socialization according to the hypotheses developed in Section 2. We thus aim for empirically representing family background, financial socialization by parents, economics at school, educational quality and financial socialization through work and money. Therefore, we combine (i.e., add up) the two items "parents encouraged savings" and "parents taught to budget” to create a summated scale for financial socialization through parents (Cronbach's alpha $=0.66$ ). We do not to include the item "financial understanding of the parents”, as this variable is rather subjective and it reduces scale reliability (alpha $=0.42$ ). Further, we use the single item "had economics in school" separately to represent the schooling channel of financial socialization.

We add the education of the mother and education of the father to create a scale for family socio-economic background (alpha $=0.88$ ). We do not include "considers economic background to be poor" in the scale, as this item has low item-rest correlation $(<0.3)$ and scale reliability would drop (to 0.72). To measure educational quality we combine "being born in Bangkok" and "having completed the highest educational degree in Bangkok" (alpha = 0.62). Finally, we create a scale for financial socialization through work and experience with money by adding "job before the age of 15" and "having a bank account before the age of 18”" (alpha $=0.18$ ). The last scale has poor reliability, but we keep it for sake of completeness, as it corresponds to the fourth factor and represents one of the three main financial socialization channels (parents, school and work/experience).

\footnotetext{
${ }^{4}$ The factor solution is rotated to facilitate interpretation, using an oblique rotation method (Promax). Oblique rotation allows for correlation among the childhood factors, which conceptually makes sense. Enforcing independent factors with Varimax rotation does not lead to meaningful differences in the factor analysis results, as the empirical correlations among the four factors are not large (see Table 4).
} 
Panel A of Table 5 shows summary statistics of the four new childhood scales, which all consist of two items and range from 0 to 2. Panel B reports the correlations of the childhood scales with financial literacy, numeracy, education and having had economics in school. The parental teaching scale has the highest correlation with financial literacy $(r=0.31)$, followed by having had economics in school $(r=0.25)$, numeracy $(r=0.24)$ and having completed higher education $(r=0.21)$. This confirms that at least one childhood factor, financial socialization through parental teaching, has an important influence on financial literacy. Panel $\mathrm{C}$ of Table 5 displays the correlations of the childhood scales with the factor scores for the first four principal components. We observe that the four scales have correlations of 0.86 and higher with the corresponding factor scores, implying that the scales capture the essence of the four childhood factors.

\subsection{The impact of childhood variables on financial literacy and numeracy}

We now analyze how the childhood variables influence financial literacy in adulthood. The results are shown in Column (3) of Table 6, while controlling for the effect of numeracy, risk aversion, education, gender, age, age squared and income. We find that financial socialization by the parents has a significant positive influence on financial literacy ( $\mathrm{p}<0.01)$. By contrast, having had economics in school is not significant. The two scales parental education and education quality are also not significant. Surprisingly, financial socialization through work and early experience with money has a negative relation with financial literacy. This is in line with results reported by Webley and Nyhus (2006). One plausible explanation is that part-time work before the age of 15 is done out of necessity and an indicator of a relatively poor upbringing. Among the control variables, both better numeracy and higher income are strongly related to higher financial literacy.

Numeracy is an important component of financial literacy, and we therefore test whether the effect of childhood variables like education quality and having had economics in school on financial literacy is indirect through better numeracy. In other words, we test whether numeracy is a mediator of the relation between the childhood financial socialization scales and financial literacy later in life. First, Column (1) of Table 6 shows the impact of the childhood variables on numeracy. We find that both financial teaching by parents, having had economics in school and better education quality significantly contribute to higher numeracy scores. In turn, higher numeracy is associated with better financial literacy in Column (3). Column (2) of Table 6 shows the impact of these childhood variables on financial literacy when numeracy is excluded, for comparison. We observe that the impact of parental teaching, having had 
economics in school and education quality on financial literacy diminishes after including numeracy in the model in Column (3), by 14\%, $24 \%$ and $45 \%$, respectively. The indirect effects of parental teaching and education quality on financial literacy through better numeracy are significant at the $5 \%$ level, while for economics in school the indirect effect is significant at the $10 \%$ level. In sum, numeracy partially mediates the relation between childhood variables and financial literacy. ${ }^{5}$

Our findings thus reveal two main channels by which childhood experiences explain adults' degree of financial literacy: the family-related channel and the schooling channel. Financial socialization by the parents, through encouraging saving and teaching budgeting, directly leads to higher financial literacy. Further, financial socialization by the parents leads to higher numeracy scores, indirectly improving financial literacy. The second channel by which childhood experiences explain financial literacy is formal schooling. Here the impact is only indirect as both better quality education and having economics in school lead to better numeracy, which in turn improves financial literacy.

\subsection{The impact on financial decisions}

So far we have established that the childhood variables are associated with higher financial literacy, and that especially financial socialization by the parents matters. An important question is whether the childhood variables also have a positive impact on financial decisions, and to what extent that effect is mediated by financial literacy. As a proxy for sound financial decision making we take the number of financial asset types owned, including fixed deposit accounts, government savings bank deposits, bonds or bond funds, stocks or stock funds, and gold. We exclude basic checking and savings accounts, as everyone in our sample owns such an account. The number of asset types is a proxy for diversification (i.e., risk management) and the decision to invest in assets that can provide a higher expected return than a simple savings account. The variable is measured on a scale from 0 to 5 , with a mean of 0.7 .

Column (4) of Table 6 shows the total effect of the childhood variables on the number of financial asset types owned. We observe that formal education matters for financial decision making: both having had economics at school and education quality have a positive impact on

\footnotetext{
${ }^{5}$ We test the significance of indirect effects with the bootstrapping method. We note that the total effects of economics in school and education quality on financial literacy are not significant in Column (2) of Table 6, while the indirect effects are significant. Kenny and Judd (2014) show that these cases frequently occur because tests for total effects and direct effects have relatively low power, especially compared with tests for indirect effects.
} 
the number of assets. Among the control variables, income, gender and higher education are significant. The positive effect of female gender may be explained by the fact that in many Thai households women take care of the financial affairs.

In Column (5) of Table 6 we add financial literacy and numeracy to the model when explaining the number of asset types owned. Financial literacy has a positive effect on the number of assets, while numeracy is insignificant. The childhood variables education quality and economics in school are still significant, with similar coefficients as before. A formal test reveals that financial literacy does not mediate the effect of the two education variables on financial decision making. However, financial literacy mediates the effect of financial teaching by parents on the number of assets, with the indirect effect significant at the $5 \%$ level. Hence, these results confirm that higher financial literacy is associated with better financial decision making, while childhood variables related to schooling also have a direct positive effect on financial decision making (not mediated by financial literacy).

\section{Robustness tests}

This section documents results of four robustness tests: (i) looking at the effect of the childhood scales on each of the financial literacy questions, (ii) discussing the effects of our variables set on more outcome variables representing sound financial behavior, (iii) replication of the results of Table 6 using Poisson regression analysis and (iv) a generalized sensitivity analysis. Finally, further exercises are mentioned and some documented in the Appendix.

Examining separated financial literacy questions. In Table 7, instead of looking at the aggregated financial literacy score, we examine the effect of childhood factors on the four financial literacy questions (items) separately. Since each question measures a slightly different aspect of financial literacy, this can help to understand the roots of financial literacy further. What becomes clear from Table 7 is that most of our results are driven by the first three questions. Financial socialization by parents has a positive effect on all on the first three items, but these are only significant at $10 \%$. Being able to answer financial literacy question 2 (about inflation) is also influenced by having more educated parents and socialization through money and work, although the latter relationship is negative. It makes sense that numeracy only improves the chance of answering questions one (interest) and two (inflation) correctly, as answering these two questions correctly requires some calculations.

The socio-demographic variables also show some interesting results. Risk aversion has an effect on question three (diversification) and four (institutional knowledge), however, these have opposite signs. It makes sense that those with higher risk aversion know more about risk 
diversification. At the same time more risk adverse respondents are less able to name foreign banks. This relationship is highly significant, possibly because those with higher risk aversion are more likely to bank at local banks. The regression results also show that the link between income and financial literacy only exists for questions two and three.

These results indicate from another angle that formal education and socialization by parent influence two different elements of financial literacy, one being able to do math, the other being a more knowledge based element of financial literacy.

Explaining other kinds of financial behavior. As robustness check in Table 8 we examine the effect of financial literacy and the childhood factors on ownership of fixed deposits, bonds (or bond funds) and stocks (or stock funds). ${ }^{6}$ These investments tend to provide a better real return in the long run than a basic savings account, and therefore offer a means to save for retirement. For sake of comparison we repeat the result for the number asset types owned in Column (4) of Table 8. The results in Table 8 indicate that a one point increase in the financial literacy score is associated with 4 percentage points higher probability of owning fixed deposits (an 11 percent increase relative to the average ownership rate of 48\%) and 2 percentage points increase in the probability of owning stocks (a 24 percent increase relative to the stock market participation rate of 9\%). Better numeracy, in contrast, does not explain investment in these assets.

Several childhood scales positively predict ownership of deposits and bonds, both financial socialization by the parents and variables related to schooling. Interestingly, ownership of stocks is not directly explained by the childhood scales, except for a negative influence of financial socialization by the parents. Hence, if the parents taught their children budgeting and encouraged them to save (higher FinSocPar), then later in life as adults they are more likely to own fixed deposits and bonds, but less likely to own stocks. Thus, the financial socialization scale is associated with safer investment choices. This may be explained by the fact that parental teaching will typically not cover complex and risky investments like stocks. However, parental teaching is still indirectly related to higher stock ownership through its positive impact on financial literacy. ${ }^{7}$

Poisson regression analysis. As a robustness check we have repeated the analysis in Table 6 using Poisson regression models that take into account the fact that numeracy and the

\footnotetext{
${ }^{6}$ Ownership of deposits, bonds and stocks is measured with 0/1 indicator variables. We use logistic regressions to explain these dependent variables and in Table 8 we display estimated marginal effects in Column (1), (2) and (3).

${ }^{7}$ Financial literacy suppresses the negative effect of FinSocPar on the ownership of stocks, with $\mathrm{p}<$ 0.1 .
} 
number of financial asset types are count variables. The results, shown in Table 9 , do not change substantially. The main difference is that the direct effect of having had economics in school on the number of asset types owned is no longer significant, while the impact of having completed higher education increases substantially (now significant at the 1\% level). Hence, one education variable (economics in school) is substituted by another (having completed higher education), without affecting the overall conclusion that higher financial literacy and schooling both contribute to better financial decisions. Financial socialization by the parents indirectly improves financial decisions, through its effect on financial literacy.

Generalized sensitivity analysis. The type of survey data we use is far from a controlled experiment as it is not possible, for example, to randomly assign what parents teach their children. Hence there are a number of potential problems. Our data is self-reported and a number of events could have influenced levels of financial literacy since childhood. Despite having a large number of control variables, we recognize that potential unobserved factors could influence the interaction between childhood scales, financial literacy and financial behavior. We therefore perform generalized sensitivity analysis (GSA) as developed by Harada (2013) and applied by Bucciol and Veronesi (2014) in our context.

Essentially, GSA generates a number of pseudo-random variables that make the coefficient of the treatment variable equal to zero. The correlation of the generated variables is then compared to the observed variables in the regression. The algorithm hence tests if the results are robust to unobserved confounders. For brevity, we only give test results for three of our main findings, the effect of financial socialization on financial literacy, the effect of economics at school on financial behavior and the effect of educational quality on financial behavior. These are shown in Figure 3. Figure 3A presents results that use financial socialization by parents as the treatment variable and Figure 3B for economics at school. For both variables an unobserved confounder would have to have a much larger correlation with financial literacy and diversification than any of the control variables in order to make the effect of financial socialization and economics at school insignificant. This can be seen as all observed factors are far below the lines in the diagrams, which represent the correlation that an unobserved confounder would have to have, in order to make the coefficient on the treatment variable equal to zero. Figure $3 \mathrm{C}$ presents results for the effect of educational quality; the observed variables here are closer to the line in the diagram. However, any unobserved confounder would have to a correlation with diversification larger than financial literacy and economics at school. It may be hard to find such an unobserved confounder. We hence conclude that our results are robust to unobserved cofounders. 
Further robustness tests. As further robustness checks, we have controlled for the respondent's amount of financial assets, and used the four childhood factors instead of the scales: in both cases, there are no changes, so that results are not presented but available on request. The Appendix presents further tests indicating the robustness of our results. These tests include the use of modified measures of financial literacy including the wide-spread Lusardi-Mitchell measure (based on three items), and the explicit consideration of the lower income part of the sample in order to see whether financial literacy has a different effect there.

\section{Conclusions}

This paper contributes to deepen our understanding about the determinants of financial literacy. Whereas earlier literature has focused on the positive impact of financial literacy on financial decision making, a result that also holds in our sample, a question that has not been answered yet is: what determines financial literacy if trainings often have such limited impacts?

We contribute to this research by analyzing the potential role of childhood experiences. Childhood variables are generally known to have a lifelong impact on the behavior of adults. Therefore, we study 12 childhood variables and organize these - in line with the literature into five different scales that potentially influence financial literacy. We expect that familyrelated, school-related and experience-related variables will have an influence on financial literacy, although it remains unclear whether these influences will hold in a joint analysis.

We find that there are two main channels by which childhood experiences influence financial literacy, the family channel and the schooling channel. First, we find that financial socialization by the parents has a positive influence on financial literacy, having the strongest impact among the five childhood factors. This result extends earlier findings by Shim et al. (2010) in a sample of U.S. high school students to a completely different sample of adults in an emerging economy, using established measures of financial literacy. Second, schooling (in the form of economics at school and educational quality) influences financial literacy indirectly by increasing numeracy, a basic skill supporting financial literacy.

We further show in our mediation analysis that financial literacy has a positive influence on financial decision making (asset diversification), mediating the effect of financial socialization by the parents. In addition, economics at school and educational quality also influence financial decisions directly, without working through financial literacy. Earlier studies by Webley and Nyhus (2006, 2013), Bucciol and Veronesi (2013) and Hira et al. (2015) demonstrate that financial teaching by the parents is related to higher savings and 
higher net household wealth. Our results suggest that these positive effects of parental teaching may partially derive from building better financial literacy, which in turn stimulates better financial decisions in adulthood.

Intriguingly, we find that financial socialization through experience with work and money in adolescence has an unexpected negative effect on financial literacy in adulthood. This result contradicts the weak positive relation between high school work experience and financial knowledge documented by Shim et al. (2010). However, our result is partially in line with the finding of Webley and Nyhus (2013) that work experience as an adolescent is negatively related to the savings of young adults, and positively related to debt levels.

It would be interesting to see in the future whether our results also hold for different data sets and whether they can be usefully extended into three directions: first, it seems interesting to complement the mediation analysis applied here by structural equation models, second, the set of variables explaining financial literacy could be enlarged or varied, and third, the kinds of financial behaviors being explained can be extended.

Overall, the importance of childhood experiences may at least partially explain why it is so difficult to train and improve adults' financial literacy in specialized courses. Together with other studies that emphasize the role of personal characteristics, this indicates that financial literacy and possibly even more financial behavior may be deeply rooted in personality. It follows that when designing training courses, the family and educational background of the target group should be considered. One may speculate whether approaches that stimulate regular savings and investment habits, through easy to understand rules and advice, may be worth considering. This could happen in addition to more conventional trainings which mostly address knowledge of financial concepts. 


\section{Acknowledgements}

We would like to thank participants at several seminars and workshops, in particular Gerrit Antonides, Alessandro Bucciol, Sebastian Braun, Martin Brown, Clemens Fuest, Olaf Hübler, Stephan Klasen, Sandra Ludwig, Olivia Mitchell, Martin Weber for helpful comments and two reviewers for excellent reports. Special thanks to Atcha Kamolsareeratana for her assistance. Financial support by the German Research Foundation (DFG, grant RTG 1723) is gratefully acknowledged. 


\section{References}

Agarwal, Sumit and Bhashkar Mazumder (2013), Cognitive Abilities and Household Financial Decision Making, American Economic Journal: Applied Economics, 5, 193-207.

Barsky, Robert B., Thomas F. Juster, Miles S. Kimball, and Mathew D. Shapiro (1997), Preference Parameters and Individual Heterogeneity: An Experimental Approach in the Health and Retirement Study, Quarterly Journal of Economics, 112:2, 537-579.

Behrman, Jere R., Olivia S. Mitchell, Cindy K. Soo and David Bravo (2010), Financial Literacy, Schooling and Wealth Accumulation, NBER Working Paper 16452.

Behrman, Jere R., Olivia S. Mitchell, Cindy K. Soo and David Bravo (2012), How Financial Literacy Affects Household Wealth Accumulation, American Economic Review Papers and Proceedings, 102:3, 300-304.

Bernheim, B. Douglas, Daniel M. Garrett and Dean M. Maki (2001), Education and Saving: The Long-term Effects of High School Financial Curriculum Mandates, Journal of Public Economics, 80, 435-465.

Bucciol, Alessandro and Marcella Veronesi (2014), Teaching Children to Save and Lifetime Savings: What is the Best Strategy? Journal of Economics Psychology, 45, 1-17.

Bucher-Koenen, Tabea and Bettina Lamla (2014), The Long Shadow of Socialism: On EastWest German Differences in Financial Literacy, MEA Discussion Paper 282-14, Munich.

Bucher-Koenen, Tabea and Annamaria Lusardi (2011), Financial Literacy and Retirement Planning in Germany, Journal of Pension Economics and Finance, 10, 565-584.

Bruhn, Miriam, Gabriel Lara Ibarra and David McKenzie (2014), The Minimal Impact of a Large-Scale Financial Education Program in Mexico, Journal of Development Economics, 108, 184-189.

Cameron, Stephen V. and James J. Heckman (2001), The Dynamics of Educational Attainment for Blacks, Hispanics, and White Males, Journal of Political Economy, 109, 455-499.

Campbell, John Y. (2006), Household Finance, Journal of Finance, 61, 1553-1604.

Carneiro, Pedro, Costas Meghir and Matthias Parey (2013), Maternal Education, Home Environments, and the Development of Children and Adolescents, Journal of the European Economic Association, 11, 123-160. 
Carlin, Bruce Ian and David T. Robinson (2012), Financial Literacy and Timely Decision Support: Lessons from Junior Achievement, American Economic Review Papers and Proceedings, 102:3, 305-308.

Carpena, Fenella, Shawn Cole, Jeremy Shapiro and Bilal Zia (2011), Unpacking the Causal Chain of Financial Literacy, World Bank Policy Research Paper 5798.

Cesarini, David, Magnus Johannesson, Paul Lichtenstein, Örjan Sandewall and Björn Wallace (2010), Genetic Variation in Financial Decision-Making, Journal of Finance, 65, 17251754.

Clark, Robert L., Melinda Sandler Morrill and Steven G. Allen (2012), The Role of Financial Literacy in Determining Retirement Plans, Economic Inquiry, 50, 851-866.

Cole, Shawn and Gauri Kartini Shastry (2009), Smart Money: The Effect of Education, Cognitive Ability and Financial Market Participation, Harvard Business School Working Paper, 09-071.

Cole, Shawn, Thomas Sampson and Bilal Zia (2011), Prices or Knowledge? What Drives Demand for Financial Services in Emerging Markets? Journal of Finance, 66, 19331967.

Christiansen, Charlotte, Juanna Schröter Joensen and Jesper Rangvid, (2008), Are Economists More Likely to Hold Stocks, Review of Finance, 12, 465-496.

Cunha, Flavio and James Heckman, The Technology of Skill Formation, American Economic Review, 97, 31-47.

Dick, Christian D. and Lena M. Jaroszek (2013), Knowing What Not to Do: Financial Literacy and Consumer Credit Choices, ZEW Discussion Paper 13-027.

Dohmen, Thomas, Armin Falk, David Huffmann and Uwe Sunde (2010), Are Risk Aversion and Impatience Related to Cognitive Ability, American Economic Review, 100, 12371260.

Dohmen, Thomas, Armin Falk, David Huffmann, Uwe Sunde, Jürgen Schupp, and Gert G. Wagner (2011), Individual Risk Attitudes: Measurement, Determinants and Behavioral Consequences, Journal of the European Economic Association, 9, 522-550.

Dohmen, Thomnas, Armin Falk, David Huffman and Uwe Sunde (2012), The Intergenerational Transmission of Risk and Trust Attitudes, Review of Economic Studies, 79, 645-677.

Fernandes, Daniel, John G. Lynch Jr. and Richard G. Netemeyer (2014), Financial Literacy, Financial Education and Downstream Financial Behaviors, Management Science, 6, 1861-1883. 
Gathergood, John (2012), Self-Control, Financial Literacy and Consumer Over-Indebtedness, Journal of Economic Psychology, 33, 590-602.

Grohmann, Antonia, Roy Kouwenberg and Lukas Menkhoff (2014), Financial Literacy and Its Consequences in the Emerging Middle Class, Kiel Working Paper 1943.

Gudmunson, Clinton and Sharon M. Danes (2011), Family Financial Socialization: Theory and Critial Review, Journal of Family Economic Issues, 32, 644-667.

Gustman, Alan L., Thomas L. Steinmeier and Nahid Tabatabai (2012), Financial Knowledge and Financial Literacy at the Household Level, American Economic Review Papers and Proceedings, 102:3, 309-313.

Guiso, Luigi and Tullio Jappelli (2008), Financial Literacy and Portfolio Choice, EUI Working Papers, ECO2008/31.

Harada, Masatake (2013), Generalized Sensitivity Analysis and Application to QuasiExperiments, Working Paper New York University.

Hardeweg, Bernd, Lukas Menkhoff and Hermann Waibel (2013), Experimentally Validated Survey Evidence on Individual Risk Attitudes in Rural Thailand, Economic Development and Cultural Change, 61, 859-888.

Heckman, James J. (2006), Skill Formation and the Economics of Investing in Disadvantaged Children, Science, 312 (No.5782), 1900-1902.

Herde, Pamela, Karen Holden and Yung Ting Su (2012), The Links between Early-Life Cognition and Schooling and Later-Life Financial Knowledge, Journal of Consumer Affairs, 46, 411-435.

Heyneman, Stephen P. and William A. Loxley (1983), The Effect of Primary-School Quality on Academic Achievement across Twenty-nine High and Low-Income Countries, American Journal of Sociology, 88, 1162-1194.

Hira, Tahira K. Mohamad Fazil Sabri and Cäzilia Loibl (2013), Financial Socialization’s Impact on Investment Orientation and Household Net Worth, International Journal of Consumer Studies, 37, 29-35.

Holt, Charles A. and Laury, Susan K. (2002), Risk Aversion and Incentive effects, American Economic Review, 92(5),1644-1655.

Hryshko, Dmytro, Maria Jose Luengo-Prado and Bent E. Sorensen (2011), Childhood Determinants of Risk Aversion: The Long Shadow of Compulsory Education, Quantitative Economics, 2, 37-72.

Jappelli, Tullio (2010), Economic Literacy: An International Comparison, Economic Journal, 120, F429-F451. 
Jappelli, Tullio and Mario Padula (2013), Investment in Financial Literacy and Savings Decisions, Journal of Banking and Finance, 37, 2779-2792.

Kenny, D. A. and C. M. Judd (2014), Power Anomalies in Testing Mediation, Psychological Science, vol. 25(2), 334-339.

Kharas, Homi (2010), The Emerging Middle Class in Developing Countries, OECD Development Centre, Working Paper 285.

Kharas, Homi and Geoffrey Gertz (2010), The New Global Middle Class: A Cross-Over from West to East, In: Cheng Li (ed.), China's Emerging Middle Class: Beyond Economic Transformation, Chapter 2, Brookings Institution Press.

Kim, Chankon, Zhiyong Yang and Hanjoon Lee (2015), Parental Style, Parental Practices and Socialization Outcomes: An Investigation of their Linkages in the Consumer Socialization Context, Journal of Economic Psychology, 49, 15-23.

Klapper, Leora, Annamaria Lusardi and Georgios A. Panos (2013), Financial Literacy and its Consequences: Evidence from Russia during the Financial Crisis, Journal of Banking and Finance, 37, 3904-3923.

Loibl, Cäzilia, David S. Kraybill, Sara Wackler DeMay (2011), Accounting for the Role of Habit in Regular Savings, Journal of Economic Psychology, 32, 581-592.

Lusardi, Annamaria and Olivia S. Mitchell (2007), Baby Boomer Retirement Security: The Roles of Planning, Financial Literacy, and Housing Wealth, Journal of Monetary Economics, 54, 205-224.

Lusardi, Annamaria and Olivia S. Mitchell (2014), The Economic Importance of Financial Literacy: Theory and Evidence, Journal of Economic Literature, 52, 5-44.

Lusardi, Annamaria, Mitchell, Olivia S. and Vilsa Curto (2010), Financial Literacy among the Young, Journal of Consumer Affairs, 44, 358-380.

Lusardi, Annamaria and Peter Tufano (2009), Debt Literacy, Financial Experiences, and Overindebtedness, NBER Working Paper 14808.

Meier, Stephan and Charles D. Sprenger (2013), Discounting Financial Literacy: Time Preference and Participation in Financial Education Programs, Journal of Economic Behavior and Organization, 95, 159-174.

Moschis, George (1985), The Role of Family Communication in Consumer Socialization of Children and Adolescents, Journal of Consumer Research, 11, 893-913.

Nyhus, Ellen K. and Webley, Paul (2013), The Relationship between Parenting and the Economic Behavior and Orientation of Norwegian Adolescents, Journal of Genetic Psychology, 174, 620-641. 
Psacharopolus, George and Harry Anthony Patrinos (2004), Returns to Investment in Education: a further Update, Education Economics, 12, 111-134.

Shim, Soyen, Bonnie L.Barber, Angela C. Lyons (2009), Pathway to Life Success: A Conceptual Model of Financial Well-being for Young Adults, Journal of Applied Developmental Psychology, 30, 208-723.

Shim, Soyeon, Bonnie L. Barber and Noel A. Card (2010), Financial Socialization of Firstyear College Students: The Roles of Parents, Work and Education, Journal of Youth and Adolescence, 39, 1457-1470.

Shim, Soyen, Joyce Serido, Chanyi Tang, Noel Card (2015), Socialization process and pathway to healthy financial development for emerging adults, Journal of Applied Developmental Psychology, 38, 29-35.

Stango, Victor and Jonathan Zinman (2009), Exponential Growth Bias and Household Finance, Journal of Finance, 64, 2807-2849.

Van Rooij, Maarten C.J., Annamaria Lusardi and Rob Alessie (2011a), Financial Literacy and Stock Market Participation, Journal of Financial Economics, 101, 449-472.

Van Rooij, Maarten C.J., Annamaria Lusardi and Rob Alessie (2011b), Financial Literacy and Retirement Planning in the Netherlands, Journal of Economic Psychology, 32, 593-608.

Van Rooij, Maarten C.J., Annamaria Lusardi and Rob J.M. Alessie (2012), Financial Literacy, Retirement Planning and Household Wealth, Economic Journal, 122, 449-478.

Webley, Paul and Ellen K. Nyhus (2006), Parents' Influence on Children’s Future Orientation and Savings, Journal of Economic Psychology, 27, 140-164.

Webley, Paul and Ellen K. Nyhus (2013), Economic Socialization, Saving and Assets in European Young Adults, Economics of Education Review, 33, 19-30.

$\mathrm{Xu}$, Lisa and Bilal Zia (2012), Financial Literacy around the World, An Overview of the Evidence with Practical Suggestions for the Way Forward, World Bank Policy Research Working Paper 6107. 
Table 1: Descriptive statistics of socio-demographic variables

\begin{tabular}{lccccc}
\hline & & & & & \\
& mean & stdev & min & max & $\mathrm{N}$ \\
\hline Female & 0.48 & 0.50 & 0 & 1 & 530 \\
Age in years & 34.58 & 9.49 & 18 & 60 & 530 \\
Married & 0.46 & 0.50 & 0 & 1 & 530 \\
Personal monthly income in Baht & 26,794 & 20,499 & 15,000 & 200,000 & 530 \\
Household monthly income in Baht & 64,353 & 99,166 & 15,000 & $2,000,000$ & 530 \\
Number of children in HH & 0.83 & 1.03 & 0 & 6 & 529 \\
Number of adults in HH & 2.97 & 1.59 & 1 & 12 & 529 \\
Number of incomes HH & 2.49 & 1.26 & 1 & 10 & 529 \\
Family status (married=1, other=0) & 0.46 & 0.49 & 0 & 1 & 530 \\
Education ${ }^{\text {a }}$ (bachelor=1, other=0) & 0.64 & 0.49 & 0 & 1 & 530 \\
Risk aversion ${ }^{\text {b }}$ (scale 0-1) & 0.49 & 0.22 & 0 & 1 & 530 \\
Numeracy & 3.56 & 0.879 & 0 & 4 & 530 \\
\hline
\end{tabular}

Notes: " Distribution of highest educational degree: “no education” or "primary school” (5\%), “secondary school” or "vocational training” (28\%), "bachelor degree” (64\%), “master degree” or "PhD” (3\%)

b The answers to the question: "Imagine you just won 100,000 Baht in a lottery and you can invest this money in a business. It is equally likely that the business goes well or not. If it goes well you can double the amount invested after one year. If it does not go well you can lose half the amount you invested. What fraction of the 100,000 would you invest in the business?” The answers have been rescaled from to 0 to 1 , and the scale has been reversed. 


\section{Table 2: Financial literacy questions and responses}

The financial literacy questions are given below. The first three questions are multiple choice and responses "I don't know" and "I refuse to answer" are available in addition to the listed options.

Item 1: Interest rate:

If you borrow 10,000 Baht, at an interest rate of $2 \%$ a month, after 3 months how much do you owe? a) Less than 10,200 Baht b) More than 10,200 Baht c) Exactly 10,200 Baht

Item 2: Inflation:

If you have 10,000 Baht in an account, the interest rate on the account is $1 \%$ per year, and the price of goods and services rises by $2 \%$ per year, after one year can you buy:

a) Less than today b) More than today c) Exactly the same as today

Item 3: Diversification:

Buying a single company's stock is safer than buying a stock mutual fund.

a) True b) False

Item 4: Institutional knowledge:

Which foreign banks operate in Thailand? (open answer)

\begin{tabular}{lccccc}
\hline & Mean & Correct (\%) & Wrong & Don't know & $\begin{array}{c}\text { Refuse to } \\
\text { answer }\end{array}$ \\
\hline Item 1 $^{\mathrm{a}}$ & 0.79 & 79.2 & 15.3 & 5.3 & 0.2 \\
Item 2 $^{\mathrm{a}}$ & 0.62 & 62.5 & 25.8 & 10.9 & 0.8 \\
Item 3 $^{\mathrm{a}}$ & 0.23 & 23.6 & 24.3 & 50.6 & 1.5 \\
Item 4 $^{\mathrm{b}}$ & 0.56 & & & & \\
Sum of items 1-3 $^{\mathrm{c}}$ & 1.65 & & & & \\
Sum of items 1-4 & 2.21 & & & & \\
\hline
\end{tabular}

Notes: " For item 1-3 the additional answer options "I don't know" and "I refuse to answer" were offered.

${ }^{\mathrm{b}}$ The number of foreign banks named varies between 0 and 4 and is divided by 4 .

${ }^{\mathrm{c}}$ This gives the Lusardi-Mitchell-measure of financial literacy. 
Table 3: Family background, formal education and financial experiences

\begin{tabular}{|c|c|c|c|c|c|}
\hline & Mean & Stdev & $\mathrm{N}$ & $\begin{array}{l}\text { Corr. } \\
\text { with } \\
\text { fin. lit. }\end{array}$ & Previously used in \\
\hline \multicolumn{6}{|l|}{ Family background } \\
\hline $\begin{array}{l}\text { Father has vocational degree } \\
\text { or higher }\end{array}$ & 0.28 & 0.45 & 474 & 0.06 & Behrman et al. (2010) \\
\hline $\begin{array}{l}\text { Mother has vocational degree } \\
\text { or higher }\end{array}$ & 0.22 & 0.42 & 479 & $0.14^{* * *}$ & Behrman et al. (2010) \\
\hline $\begin{array}{l}\text { Financial understanding } \\
\text { of parents (1-6) }\end{array}$ & 4.39 & 1.53 & 516 & $0.25^{* * *}$ & van Rooij et al. (2011b) \\
\hline $\begin{array}{l}\text { Considers economic } \\
\text { background to be poor }\end{array}$ & 0.28 & 0.45 & 504 & -0.06 & Behrman et al. (2010) \\
\hline \multicolumn{6}{|l|}{ Financial socialization by parents } \\
\hline Parents taught to budget & 0.83 & 0.38 & 527 & $0.23^{* * *}$ & Webley and Nyhus (2013) \\
\hline $\begin{array}{l}\text { Parents encouraged saving } \\
\text { between } 12 \text { and } 16\end{array}$ & 0.86 & 0.35 & 515 & $0.25^{* * *}$ & Webley and Nyhus (2013) \\
\hline \multicolumn{6}{|l|}{ Economics at school } \\
\hline Had economics in school & 0.67 & 0.47 & 519 & $0.11^{* *}$ & van Rooij et al. (2011a) \\
\hline \multicolumn{6}{|l|}{ Educational quality } \\
\hline Was born in Bangkok & 0.64 & 0.48 & 530 & $0.13^{* * *}$ & Behrman et al. (2010) \\
\hline $\begin{array}{l}\text { Completed highest educational } \\
\text { degree in Bangkok }\end{array}$ & 0.87 & 0.34 & 530 & $0.16^{* * *}$ & Behrman et al. (2010) \\
\hline \multicolumn{6}{|l|}{ Early experiences with money } \\
\hline Had allowance as a child & 0.99 & 0.09 & 523 & 0.02 & Webley and Nyhus (2013) \\
\hline Had bank account before 18 & 0.57 & 0.50 & 517 & $-0.13^{* * *}$ & Webley and Nyhus (2013) \\
\hline Had job before age 15 & 0.47 & 0.50 & 526 & -0.01 & Behrman et al. (2010) \\
\hline
\end{tabular}

Notes: ${ }^{\text {a }}$ We classify vocational training, bachelor and master degree as better education vs. lower education consisting of no formal education, primary or secondary school only. The column 'Corr. with fin. lit.' shows the correlation of the childhood experience variables with our financial literacy measure. ***, ** and $*$ denote significance at the $1 \%, 5 \%$ and $10 \%$ levels, respectively. 
Table 4: Factor analysis of childhood variables

Panel A: Factor loadings

\begin{tabular}{lcccc} 
& & & & \\
& Factor1 & Factor2 & Factor3 & Factor4 \\
\hline Taught to budget & $\mathbf{0 . 8 8}$ & -0.09 & -0.02 & 0.05 \\
Encouraged to save & $\mathbf{0 . 8 9}$ & -0.03 & 0.03 & 0.05 \\
Financial underst. of parents & $\mathbf{0 . 7 0}$ & -0.12 & 0.08 & $\mathbf{- 0 . 5 1}$ \\
Economics at school & $\mathbf{0 . 7 6}$ & 0.11 & 0.00 & 0.05 \\
Bank account before 18 & 0.35 & 0.41 & -0.26 & $\mathbf{0 . 5 8}$ \\
Job before 15 & -0.01 & -0.29 & 0.12 & $\mathbf{0 . 7 8}$ \\
Educational attainment father & -0.05 & $\mathbf{0 . 9 2}$ & 0.13 & -0.06 \\
Educational attainment mother & -0.01 & $\mathbf{0 . 8 8}$ & 0.27 & 0.00 \\
Poor economic background & 0.07 & $-\mathbf{0 . 5 3}$ & 0.26 & 0.40 \\
Born in Bangkok & -0.14 & 0.21 & $\mathbf{0 . 9 3}$ & 0.09 \\
Highest degree Bangkok & 0.22 & 0.11 & $\mathbf{0 . 8 6}$ & -0.07 \\
\hline
\end{tabular}

Panel B: Eigenvalues

\begin{tabular}{lcccc} 
& Factor1 & Factor2 & Factor3 & Factor4 \\
\hline Eigenvalues & 2.92 & 2.42 & 1.94 & 1.49 \\
\% Explained & $26.6 \%$ & $22.0 \%$ & $17.6 \%$ & $13.5 \%$ \\
\% Cumulative & $26.6 \%$ & $48.6 \%$ & $66.2 \%$ & $79.7 \%$ \\
\hline
\end{tabular}

Panel C: Factor correlations

\begin{tabular}{lcccc}
\hline Correlations & & & & \\
& Factor1 & Factor2 & Factor3 & Factor4 \\
\hline Factor1 & 1 & .19 & .08 & .06 \\
Factor2 & .19 & 1 & .06 & -.11 \\
Factor3 & .08 & .06 & 1 & -.10 \\
Factor4 & .06 & -.11 & -.10 & 1 \\
\hline
\end{tabular}

Note: the table shows a factor analysis of 11 childhood variables, using the principal components method. Panel A displays factor solution after oblique rotation (Promax). Panel B shows the eigenvalues of the factors and the percentage of total variation explained. Four factors were extracted, based on the eigenvalue $(>1)$ criterion. Oblique rotation allows for correlation among the factors: the correlations among the factors are shown in Panel C. 
Table 5: Summary statistics and correlation of the childhood scales

Panel A: Descriptive statistics

\begin{tabular}{lccccc}
\hline & mean & sd & min & max & count \\
\hline $\begin{array}{l}\text { ParEdu: } \\
\quad \text { Education of parents }\end{array}$ & 0.67 & 0.47 & 0 & 2 & 470 \\
$\begin{array}{l}\text { FinSocPar: } \\
\quad \text { Financial socialization by parents }\end{array}$ & 1.69 & 0.62 & 0 & 2 & 513 \\
$\begin{array}{l}\text { EduQual: } \\
\quad \text { Education quality }\end{array}$ & 1.50 & 0.71 & 0 & 2 & 530 \\
$\begin{array}{l}\text { FinSocMoney: Financial social. through } \\
\text { experience with work and money }\end{array}$ & 1.05 & 0.74 & 0 & 2 & 515 \\
\hline
\end{tabular}

\section{Panel B: Correlations with financial literacy, numeracy and education}

\begin{tabular}{lccccc}
\hline & $\begin{array}{c}\text { Financial } \\
\text { literacy }\end{array}$ & ParEdu & FinSocPar & EduQual & $\begin{array}{c}\text { FinSoc- } \\
\text { Money }\end{array}$ \\
\hline ParEdu & 0.09 & 1 & & & \\
FinSocPar & 0.31 & 0.04 & 1 & & \\
EduQual & 0.14 & 0.26 & 0.06 & 1 & \\
FinSocMoney & -0.06 & -0.09 & 0.30 & -0.12 & 1 \\
Economics in school & 0.25 & 0.19 & 0.61 & 0.06 & 0.14 \\
Numeracy & 0.24 & 0.08 & 0.35 & 0.28 & -0.03 \\
Higher education & 0.21 & 0.46 & 0.28 & 0.34 & -0.18 \\
\hline
\end{tabular}

Panel C: Correlations with the four extracted factors (components)

\begin{tabular}{lcccc} 
& Factor1 & Factor2 & Factor3 & Factor4 \\
\hline ParEdu & 0.14 & 0.86 & 0.08 & -0.16 \\
FinSocPar & 0.94 & 0.06 & 0.07 & 0.11 \\
EduQual & 0.06 & 0.08 & 1.00 & -0.03 \\
FinSocMoney & 0.25 & 0.02 & -0.11 & 0.95 \\
\hline
\end{tabular}

Note: Panel A of the table displays descriptive statistics of the summated scales constructed from the childhood variables. Panel B shows correlations between the scales and financial literacy, numeracy, an indicator for having had economics in school and an indicator for having completed higher education. Panel C shows the correlations between the four scales and factor scores for the first four principal components from the factor analysis shown in Table 4. FinSocPar is a scale for financial socialization through parental teaching, define as the sum of "parents encouraged savings" and "parents taught to budget" (alpha = 0.66). ParEdu is a scale for family socio-economic background, measured as the sum of the education level of the mother and the education level of the father to (alpha $=0.88$ ), rescaled to range from 0 to 2. EduQual is a scale for educational quality, defined as the sum of "being born in Bangkok" and "having completed the highest educational degree in Bangkok" (alpha =0.62). FinSocMoney is a scale for financial socialization through work and experience with money, defined as the sum of "job before the age of 15" and "having a bank account before the age of 18" (alpha $=0.18$ ). 
Table 6: Childhood variables, financial literacy, numeracy and financial decisions

\begin{tabular}{|c|c|c|c|c|c|}
\hline \multirow{2}{*}{$\begin{array}{l}\text { Numeracy } \\
\end{array}$} & \multirow[t]{2}{*}{$\begin{array}{c}(1) \\
\text { Numeracy }\end{array}$} & \multicolumn{2}{|c|}{$\begin{array}{l}(2) \\
\text { Financial literacy }\end{array}$} & \multicolumn{2}{|c|}{$\begin{array}{l}(4) \\
\text { Number of assets }\end{array}$} \\
\hline & & & $\begin{array}{c}0.14^{* * *} \\
{[0.05]}\end{array}$ & & $\begin{array}{l}-0.01 \\
{[0.04]}\end{array}$ \\
\hline Financial literacy & & & & & $\begin{array}{c}0.09 * * * \\
{[0.04]}\end{array}$ \\
\hline ParEdu & $\begin{array}{l}-0.11 \\
{[0.09]}\end{array}$ & $\begin{array}{c}0.09 \\
{[0.10]}\end{array}$ & $\begin{array}{c}0.10 \\
{[0.10]}\end{array}$ & $\begin{array}{c}0.12 \\
{[0.08]}\end{array}$ & $\begin{array}{c}0.12 \\
{[0.08]}\end{array}$ \\
\hline FinSocPar & $\begin{array}{c}0.32 * * * \\
{[0.07]}\end{array}$ & $\begin{array}{c}0.31^{* * * *} \\
{[0.08]}\end{array}$ & $\begin{array}{c}0.26^{* * *, a} \\
{[0.08]}\end{array}$ & $\begin{array}{c}0.06 \\
{[0.06]}\end{array}$ & $\begin{array}{c}0.03^{\mathrm{d}} \\
{[0.06]}\end{array}$ \\
\hline Economics in school & $\begin{array}{l}0.26 * * \\
{[0.11]}\end{array}$ & $\begin{array}{c}0.14 \\
{[0.12]}\end{array}$ & $\begin{array}{l}0.11^{\mathrm{b}} \\
{[0.11]}\end{array}$ & $\begin{array}{l}0.18 * * \\
{[0.09]}\end{array}$ & $\begin{array}{l}0.17 * * \\
{[0.09]}\end{array}$ \\
\hline EduQual & $\begin{array}{c}0.25^{* * *} \\
{[0.06]}\end{array}$ & $\begin{array}{c}0.07 \\
{[0.06]}\end{array}$ & $\begin{array}{l}0.04^{\mathrm{C}} \\
{[0.06]}\end{array}$ & $\begin{array}{l}0.10^{* *} \\
{[0.05]}\end{array}$ & $\begin{array}{l}0.10 * * \\
{[0.05]}\end{array}$ \\
\hline FinSocMoney & $\begin{array}{l}-0.05 \\
{[0.06]}\end{array}$ & $\begin{array}{c}-0.13^{* *} \\
{[0.06]}\end{array}$ & $\begin{array}{c}-0.12^{* *} \\
{[0.06]}\end{array}$ & $\begin{array}{l}-0.01 \\
{[0.05]}\end{array}$ & $\begin{array}{l}0.001 \\
{[0.05]}\end{array}$ \\
\hline Risk aversion & $\begin{array}{l}-0.34^{*} \\
{[0.19]}\end{array}$ & $\begin{array}{l}-0.18 \\
{[0.21]}\end{array}$ & $\begin{array}{l}-0.13 \\
{[0.20]}\end{array}$ & $\begin{array}{c}0.22 \\
{[0.16]}\end{array}$ & $\begin{array}{c}0.23 \\
{[0.15]}\end{array}$ \\
\hline Higher education & $\begin{array}{l}-0.01 \\
{[0.10]}\end{array}$ & $\begin{array}{c}0.04 \\
{[0.11]}\end{array}$ & $\begin{array}{c}0.05 \\
{[0.11]}\end{array}$ & $\begin{array}{l}0.16^{*} \\
{[0.08]}\end{array}$ & $\begin{array}{l}0.16^{*} \\
{[0.08]}\end{array}$ \\
\hline Female & $\begin{array}{c}0.03 \\
{[0.08]}\end{array}$ & $\begin{array}{c}0.06 \\
{[0.09]}\end{array}$ & $\begin{array}{c}0.06 \\
{[0.09]}\end{array}$ & $\begin{array}{c}0.21 * * * \\
{[0.07]}\end{array}$ & $\begin{array}{c}0.21 * * * \\
{[0.07]}\end{array}$ \\
\hline Age & $\begin{array}{c}0.01 \\
{[0.03]}\end{array}$ & $\begin{array}{c}0.01 \\
{[0.04]}\end{array}$ & $\begin{array}{c}0.01 \\
{[0.04]}\end{array}$ & $\begin{array}{c}0.04 \\
{[0.03]}\end{array}$ & $\begin{array}{c}0.04 \\
{[0.03]}\end{array}$ \\
\hline Age squared & $\begin{array}{l}-0.03 \\
{[0.05]}\end{array}$ & $\begin{array}{l}-0.02 \\
{[0.05]}\end{array}$ & $\begin{array}{l}-0.01 \\
{[0.05]}\end{array}$ & $\begin{array}{l}-0.04 \\
{[0.04]}\end{array}$ & $\begin{array}{l}-0.03 \\
{[0.04]}\end{array}$ \\
\hline Log of income & $\begin{array}{c}0.33 * * * \\
{[0.11]}\end{array}$ & $\begin{array}{c}0.36^{* * * *} \\
{[0.12]}\end{array}$ & $\begin{array}{c}0.31 * * * \\
{[0.11]}\end{array}$ & $\begin{array}{c}1.06 * * * \\
{[0.09]}\end{array}$ & $\begin{array}{c}1.03 * * * \\
{[0.09]}\end{array}$ \\
\hline Constant & $\begin{array}{c}1.92 * * * \\
{[0.67]}\end{array}$ & $\begin{array}{c}0.35 \\
{[0.73]}\end{array}$ & $\begin{array}{c}0.09 \\
{[0.72]}\end{array}$ & $\begin{array}{c}-4.21 * * * \\
{[0.56]}\end{array}$ & $\begin{array}{c}-4.24 * * * \\
{[0.55]}\end{array}$ \\
\hline $\begin{array}{l}\mathrm{R}^{2} \\
\text { Observations }\end{array}$ & $\begin{array}{l}0.20 \\
435\end{array}$ & $\begin{array}{c}0.11 \\
435\end{array}$ & $\begin{array}{l}0.12 \\
435\end{array}$ & $\begin{array}{c}0.44 \\
435\end{array}$ & $\begin{array}{l}0.45 \\
435\end{array}$ \\
\hline
\end{tabular}

Note: the table reports OLS regressions explaining numeracy (Column 1), financial literacy (Column 2) and the number of financial asset types (Column 4) with the childhood variables and a set of control variables. In addition, a system of equations for numeracy (Column 1), financial literacy (Column 3) and number of asset types (Column 5) was estimated jointly with seemingly related regressions method (SUR). The SUR regressions results were then used to test for mediating effects.

$* \mathrm{p}<0.1, * * \mathrm{p}<0.05, * * * \mathrm{p}<0.01$

${ }^{a}$ Numeracy mediates the relation between financial socialization by parents and financial literacy $(\mathrm{p}<0.05)$.

${ }^{b}$ Numeracy mediates the relation between "had economics in school" and financial literacy $(\mathrm{p}<0.10)$.

${ }^{\mathrm{c}}$ Numeracy mediates the relation between education quality and financial literacy $(\mathrm{p}<0.05)$.

${ }^{\mathrm{d}}$ Financial literacy mediates the relation between financial socialization by parents and number of assets $(\mathrm{p}<0.05)$. 
Table 7: The effect of childhood roots on financial literacy items

\begin{tabular}{|c|c|c|c|c|}
\hline & $\begin{array}{c}(1) \\
\text { Item } 1 \\
\text { Interest rates }\end{array}$ & $\begin{array}{c}(2) \\
\text { Item } 2 \\
\text { Inflation } \\
\end{array}$ & $\begin{array}{c}(3) \\
\text { Item } 3 \\
\text { Diversification }\end{array}$ & $\begin{array}{c}(4) \\
\text { Item } 4 \\
\text { Name banks }\end{array}$ \\
\hline ParEdu & $\begin{array}{c}-0.232 \\
{[0.164]}\end{array}$ & $\begin{array}{l}0.256 * \\
{[0.146]}\end{array}$ & $\begin{array}{c}0.226 \\
{[0.164]}\end{array}$ & $\begin{array}{c}0.061 \\
{[0.289]}\end{array}$ \\
\hline FinSocPar & $\begin{array}{c}0.205^{*} \\
{[0.119]}\end{array}$ & $\begin{array}{l}0.207^{*} \\
{[0.119]}\end{array}$ & $\begin{array}{c}0.253 * \\
{[0.142]}\end{array}$ & $\begin{array}{c}0.127 \\
{[0.159]}\end{array}$ \\
\hline Economics at school & $\begin{array}{c}0.223 \\
{[0.179]}\end{array}$ & $\begin{array}{c}0.079 \\
{[0.170]}\end{array}$ & $\begin{array}{c}-0.191 \\
{[0.194]}\end{array}$ & $\begin{array}{c}0.266 \\
{[0.250]}\end{array}$ \\
\hline EduQual & $\begin{array}{c}-0.010 \\
{[0.104]}\end{array}$ & $\begin{array}{l}-0.048 \\
{[0.094]}\end{array}$ & $\begin{array}{c}0.166 \\
{[0.107]}\end{array}$ & $\begin{array}{c}-0.150 \\
{[0.157]}\end{array}$ \\
\hline FinSocMoney & $\begin{array}{c}0.050 \\
{[0.101]}\end{array}$ & $\begin{array}{c}-0.182^{* *} \\
{[0.092]}\end{array}$ & $\begin{array}{c}-0.114 \\
{[0.101]}\end{array}$ & $\begin{array}{c}-0.126 \\
{[0.117]}\end{array}$ \\
\hline Numeracy & $\begin{array}{c}0.157 * \\
{[0.080]}\end{array}$ & $\begin{array}{c}0.211 * * * \\
{[0.078]}\end{array}$ & $\begin{array}{c}0.059 \\
{[0.083]}\end{array}$ & $\begin{array}{c}-0.045 \\
{[0.098]}\end{array}$ \\
\hline Risk aversion & $\begin{array}{c}0.274 \\
{[0.352]}\end{array}$ & $\begin{array}{c}-0.257 \\
{[0.307]}\end{array}$ & $\begin{array}{l}0.654 * \\
{[0.349]}\end{array}$ & $\begin{array}{c}-1.750 * * * \\
{[0.501]}\end{array}$ \\
\hline Higher education & $\begin{array}{c}0.175 \\
{[0.178]}\end{array}$ & $\begin{array}{c}0.042 \\
{[0.164]}\end{array}$ & $\begin{array}{c}-0.177 \\
{[0.188]}\end{array}$ & $\begin{array}{c}0.460 * \\
{[0.259]}\end{array}$ \\
\hline Female & $\begin{array}{c}-0.023 \\
{[0.144]}\end{array}$ & $\begin{array}{c}0.011 \\
{[0.129]}\end{array}$ & $\begin{array}{c}0.125 \\
{[0.145]}\end{array}$ & $\begin{array}{c}0.047 \\
{[0.210]}\end{array}$ \\
\hline Age & $\begin{array}{c}-0.088 \\
{[0.058]}\end{array}$ & $\begin{array}{c}0.043 \\
{[0.054]}\end{array}$ & $\begin{array}{c}0.025 \\
{[0.059]}\end{array}$ & $\begin{array}{c}0.121 \\
{[0.074]}\end{array}$ \\
\hline Age squared & $\begin{array}{c}0.117 \\
{[0.078]}\end{array}$ & $\begin{array}{c}-0.075 \\
{[0.074]}\end{array}$ & $\begin{array}{c}-0.031 \\
{[0.080]}\end{array}$ & $\begin{array}{c}-0.167 \\
{[0.103]}\end{array}$ \\
\hline Log of income & $\begin{array}{c}0.225 \\
{[0.207]}\end{array}$ & $\begin{array}{c}0.428 * * \\
{[0.206]}\end{array}$ & $\begin{array}{c}0.406 * * \\
{[0.174]}\end{array}$ & $\begin{array}{c}0.119 \\
{[0.236]}\end{array}$ \\
\hline Constant & $\begin{array}{c}0.517 \\
{[1.169]}\end{array}$ & $\begin{array}{c}-2.491^{* *} \\
{[1.142]}\end{array}$ & $\begin{array}{c}-3.630^{* * *} \\
{[1.159]}\end{array}$ & $\begin{array}{c}0.005 \\
{[1.434]}\end{array}$ \\
\hline $\begin{array}{l}\text { pseduo-R }{ }^{2} \\
\text { Observations }\end{array}$ & $\begin{array}{l}0.06 \\
439 \\
\end{array}$ & $\begin{array}{l}0.07 \\
439 \\
\end{array}$ & $\begin{array}{l}0.05 \\
439 \\
\end{array}$ & $\begin{array}{l}0.15 \\
439 \\
\end{array}$ \\
\hline
\end{tabular}

Notes: The table reports Probit and Poisson regression results with robust standard errors in brackets. The dependent variable in columns 1 to 3 is unity if the respective question was correct. Column 4 takes value of 1 to 4 for each foreign bank that was named. $* * *, * *$ and $*$ denote significance at the $1 \%, 5 \%$ and $10 \%$ levels, respectively. 
Table 8: Explaining ownership of fixed deposits, bonds and stocks

\begin{tabular}{|c|c|c|c|c|}
\hline & $\begin{array}{c}\text { (1) } \\
\text { Fixed } \\
\text { deposits }\end{array}$ & $\begin{array}{c}\text { (2) } \\
\text { Bonds }\end{array}$ & $\begin{array}{c}\text { (3) } \\
\text { Stocks }\end{array}$ & $\begin{array}{c}\text { (4) } \\
\text { Number of } \\
\text { assets }\end{array}$ \\
\hline Financial literacy & $\begin{array}{c}0.040^{*} \\
{[0.023]}\end{array}$ & $\begin{array}{c}-0.006 \\
{[0.014]}\end{array}$ & $\begin{array}{l}0.022^{*} \\
{[0.013]}\end{array}$ & $\begin{array}{c}0.094 * * * \\
{[0.037]}\end{array}$ \\
\hline Numeracy & $\begin{array}{l}0.005 \\
{[0.03]}\end{array}$ & $\begin{array}{c}0.003 \\
{[0.02]}\end{array}$ & $\begin{array}{c}-0.019 \\
{[0.014]}\end{array}$ & $\begin{array}{l}-0.005 \\
{[0.04]}\end{array}$ \\
\hline ParEdu & $\begin{array}{l}0.10 * * \\
{[0.05]}\end{array}$ & $\begin{array}{c}0.01 \\
{[0.03]}\end{array}$ & $\begin{array}{c}-0.04 \\
{[0.03]}\end{array}$ & $\begin{array}{c}0.12 \\
{[0.08]}\end{array}$ \\
\hline FinSocPar & $\begin{array}{l}0.08^{*, a} \\
{[0.04]}\end{array}$ & $\begin{array}{l}0.07 * * \\
{[0.03]}\end{array}$ & $\begin{array}{c}-0.04 * *, \mathrm{~b} \\
{[0.02]}\end{array}$ & $\begin{array}{c}0.03^{\mathrm{C}} \\
{[0.06]}\end{array}$ \\
\hline Economics in school & $\begin{array}{c}0.06 \\
{[0.06]}\end{array}$ & $\begin{array}{l}0.07^{*} \\
{[0.04]}\end{array}$ & $\begin{array}{c}0.02 \\
{[0.03]}\end{array}$ & $\begin{array}{c}0.17 * * \\
{[0.09]}\end{array}$ \\
\hline EduQual & $\begin{array}{c}0.07 * * \\
{[0.03]}\end{array}$ & $\begin{array}{c}0.03 \\
{[0.02]}\end{array}$ & $\begin{array}{c}-0.01 \\
{[0.02]}\end{array}$ & $\begin{array}{l}0.10 * * \\
{[0.05]}\end{array}$ \\
\hline FinSocMoney & $\begin{array}{c}-0.01 \\
{[0.03]}\end{array}$ & $\begin{array}{l}0.0001 \\
{[0.02]}\end{array}$ & $\begin{array}{c}0.01 \\
{[0.02]}\end{array}$ & $\begin{array}{l}0.001 \\
{[0.05]}\end{array}$ \\
\hline Risk aversion & $\begin{array}{l}-0.10 \\
{[0.10]}\end{array}$ & $\begin{array}{c}0.03 \\
{[0.06]}\end{array}$ & $\begin{array}{l}0.10^{*} \\
{[0.05]}\end{array}$ & $\begin{array}{c}0.23 \\
{[0.15]}\end{array}$ \\
\hline Higher education & $\begin{array}{c}0.06 \\
{[0.06]}\end{array}$ & $\begin{array}{c}-0.02 \\
{[0.04]}\end{array}$ & $\begin{array}{c}0.09 * * * \\
{[0.02]}\end{array}$ & $\begin{array}{l}0.16^{*} \\
{[0.08]}\end{array}$ \\
\hline Female & $\begin{array}{c}0.09 * * \\
{[0.04]}\end{array}$ & $\begin{array}{l}0.06 * * \\
{[0.03]}\end{array}$ & $\begin{array}{c}-0.02 \\
{[0.02]}\end{array}$ & $\begin{array}{c}0.21 * * * \\
{[0.07]}\end{array}$ \\
\hline Age & $\begin{array}{c}0.03 \\
{[0.02]}\end{array}$ & $\begin{array}{c}0.04 * * * \\
{[0.01]}\end{array}$ & $\begin{array}{c}-0.01 \\
{[0.01]}\end{array}$ & $\begin{array}{c}0.04 \\
{[0.03]}\end{array}$ \\
\hline Age squared & $\begin{array}{c}-0.03 \\
{[0.03]}\end{array}$ & $\begin{array}{c}-0.044^{* * *} \\
{[0.017]}\end{array}$ & $\begin{array}{c}0.01 \\
{[0.01]}\end{array}$ & $\begin{array}{c}-0.03 \\
{[0.04]}\end{array}$ \\
\hline Log of income & $\begin{array}{c}0.24 * * * \\
{[0.06]}\end{array}$ & $\begin{array}{l}0.16^{* *} \\
{[0.03]}\end{array}$ & $\begin{array}{c}0.12^{* * *} \\
{[0.02]}\end{array}$ & $\begin{array}{c}1.03^{* * *} \\
{[0.09]}\end{array}$ \\
\hline $\begin{array}{l}\text { Pseudo-R }^{2} \\
\mathrm{~N}\end{array}$ & $\begin{array}{l}0.17 \\
439 \\
\end{array}$ & $\begin{array}{l}0.27 \\
438 \\
\end{array}$ & $\begin{array}{l}0.33 \\
437 \\
\end{array}$ & $\begin{array}{c}0.45 \\
435 \\
\end{array}$ \\
\hline
\end{tabular}

Note: the table reports logistic regression results explaining ownership of fixed deposits (Column 1), bonds or bond funds (Column 2) and stocks or stock funds (Column 3) by financial literacy, numeracy, the childhood scales, and a set of control variables. Column 1 to 3 show estimated marginal effects, with standard errors in brackets below. For comparison sake Column 4 shows regression results for the number of asset types owned, repeating the same information as in Column 5 of Table 6 .

* $\mathrm{p}<0.1, * * \mathrm{p}<0.05, * * * \mathrm{p}<0.01$

${ }^{a}$ Financial literacy mediates FinSocPar's positive effect on fixed deposit ownership $(\mathrm{p}<0.1)$.

${ }^{\mathrm{b}}$ Financial literacy suppresses FinSocPar's negative effect on stock ownership $(\mathrm{p}<0.1)$.

${ }^{c}$ Financial literacy mediates FinSocPar's positive effect on the number of asset types owned $(p<0.05)$. 
Table 9: Childhood variables, financial literacy, numeracy and financial decisions, with Poisson regressions for numeracy and number of assets

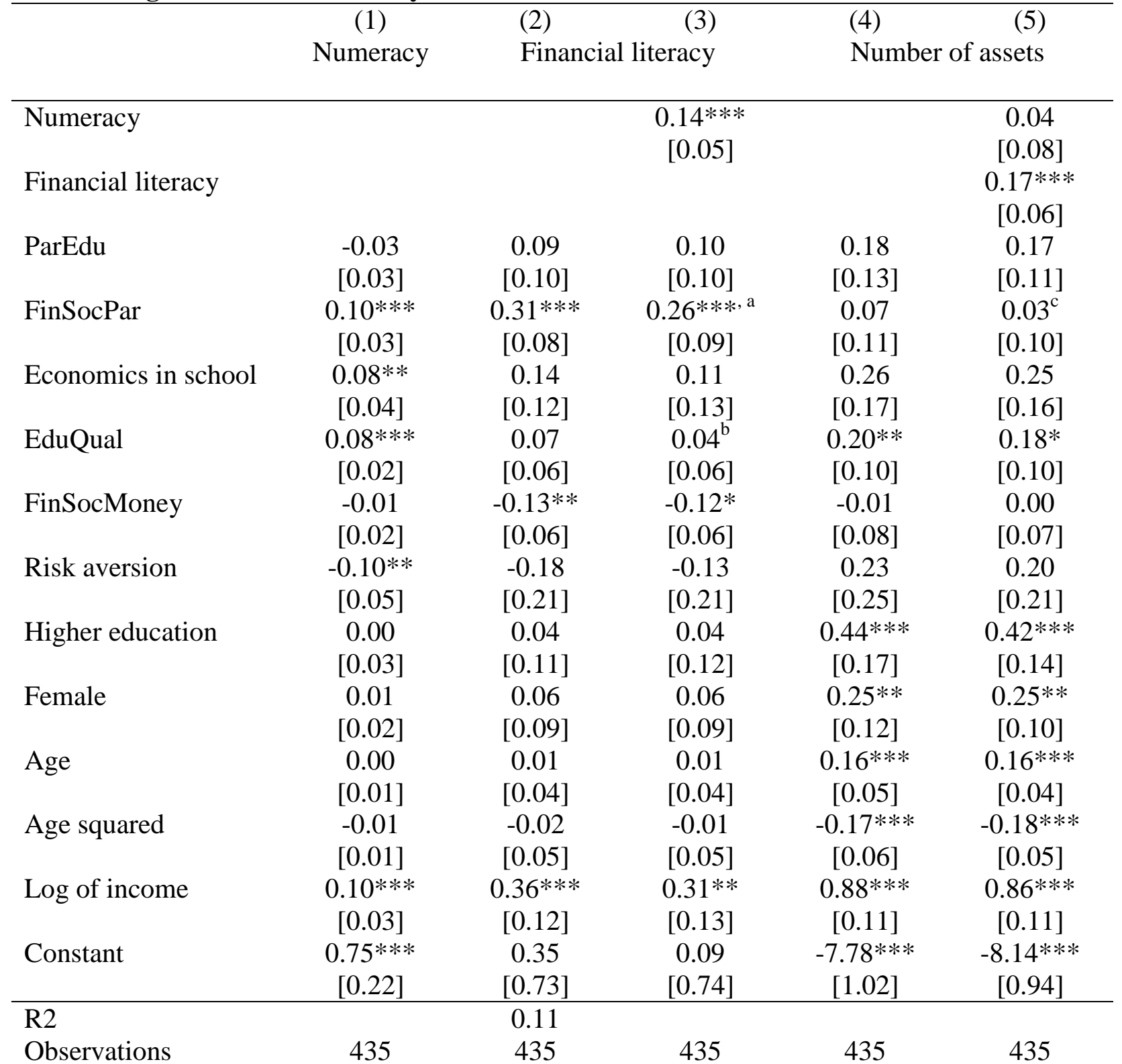

Note: the table reports regressions explaining numeracy (Column 1), financial literacy (Column 2) and the number of financial asset types (Column 4) with the childhood variables and a set of control variables. For the count variables numeracy and number of financial asset types a Poisson regression model was estimated, while the equation for financial literacy (including number of banks named) was estimated with OLS. In addition, a system of equations for numeracy (Column 1), financial literacy (Column 3) and number of asset types (Column 5) was estimated jointly with seemingly related regressions method (SUR), using Poisson regressions for numeracy and number of asset types. The SUR regressions results were then used to test for mediating effects.

${ }^{*} \mathrm{p}<0.1, * * \mathrm{p}<0.05, * * * \mathrm{p}<0.01$

${ }^{a}$ Numeracy mediates the relation between financial socialization by parents and financial literacy $(\mathrm{p}<0.05)$.

${ }^{\mathrm{b}}$ Numeracy mediates the relation between education quality and financial literacy $(\mathrm{p}<0.05)$.

${ }^{\mathrm{c}}$ Financial literacy mediates the relation between financial socialization by parents and number of assets $(\mathrm{p}<0.05)$. 
Figure 1: Relations between childhood, financial literacy and financial behavior

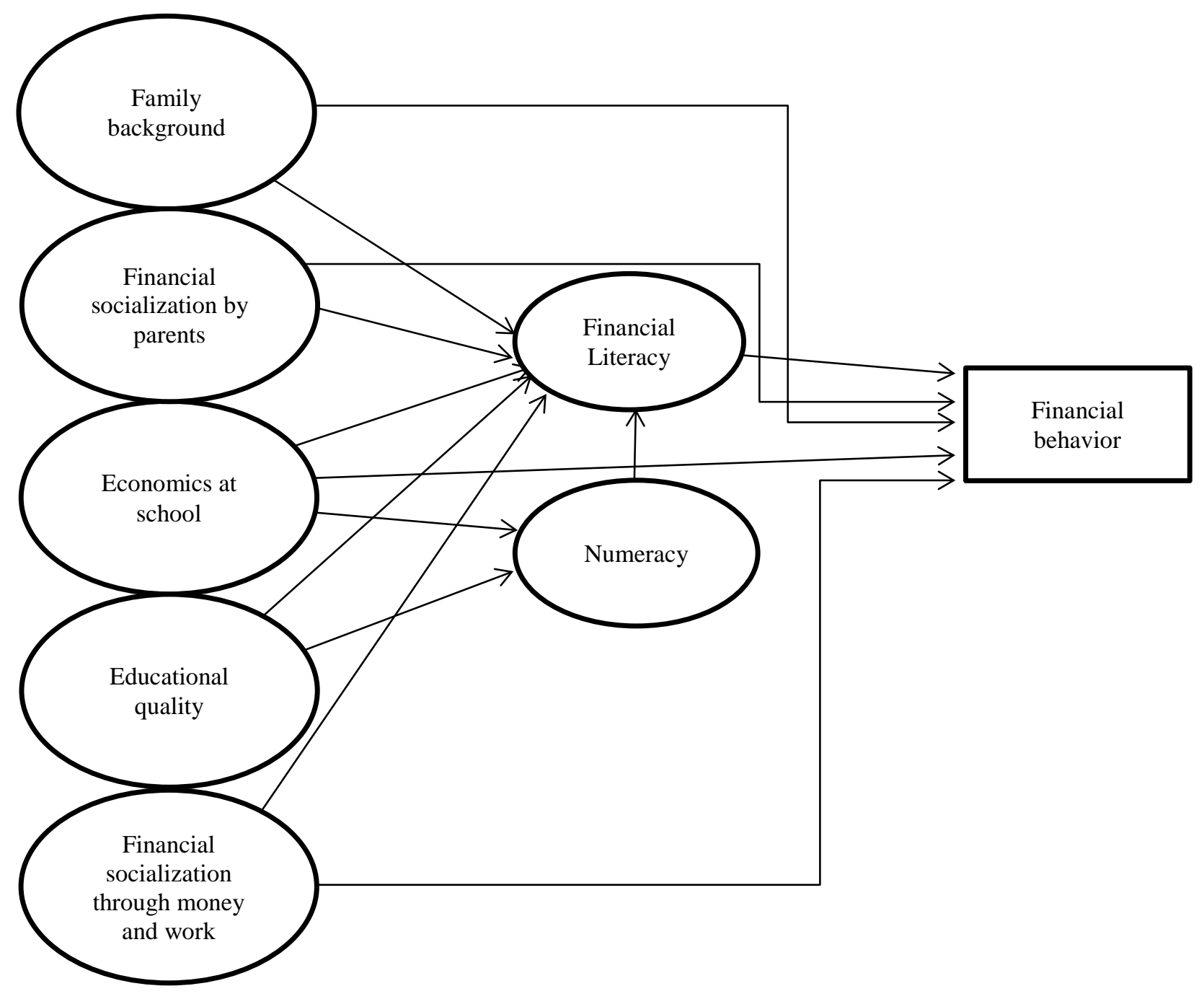


Figure 2: Distribution of financial literacy

Panel A: Score on Lusardi-Mitchell questions (0 - 3)

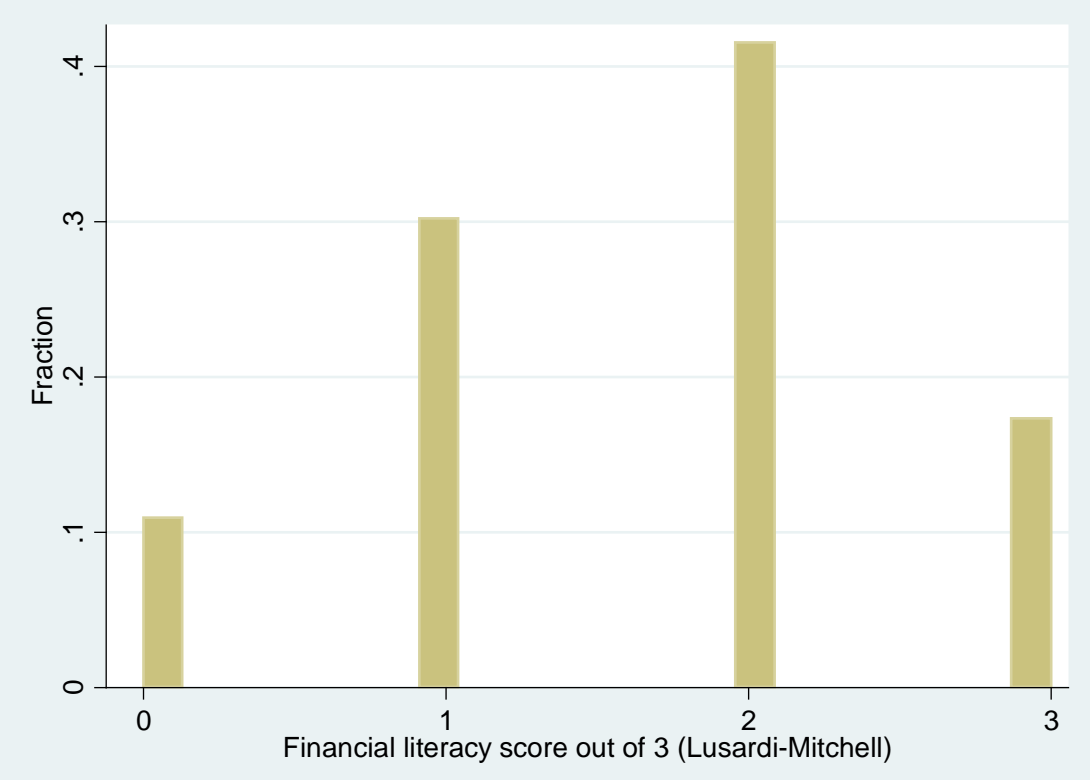

Panel B: Lusardi-Mitchell plus name banks score (0 - 4)

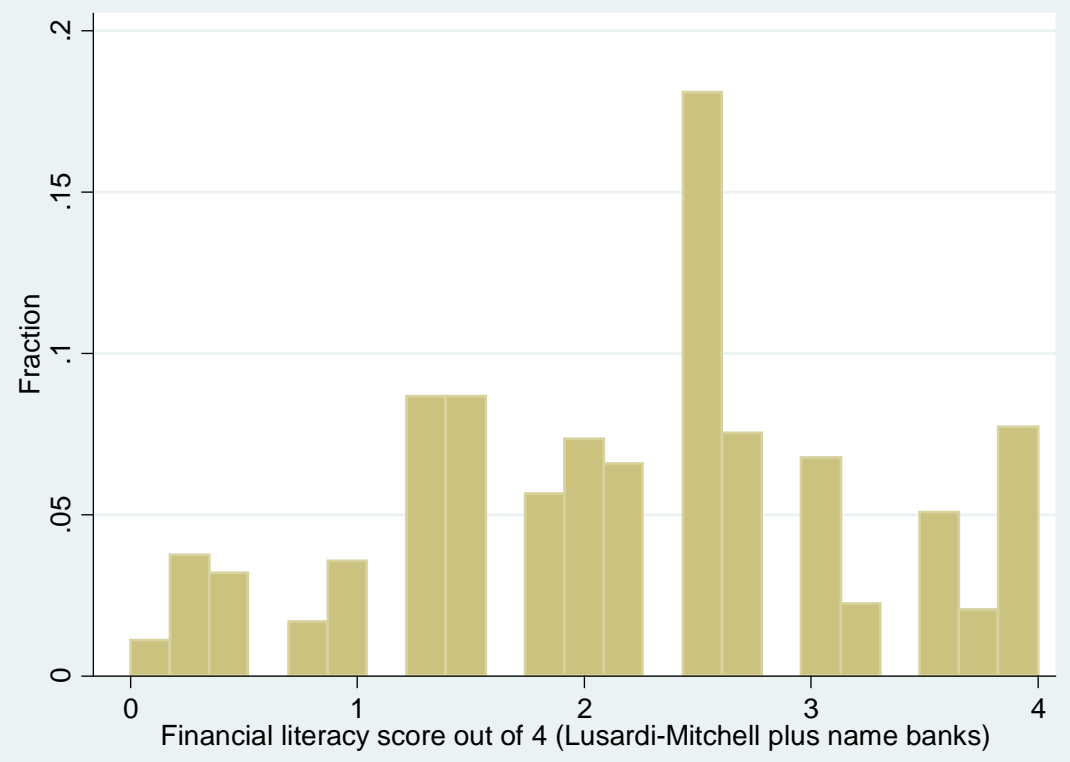


Figure 3: Generalized Sensitivity Analysis

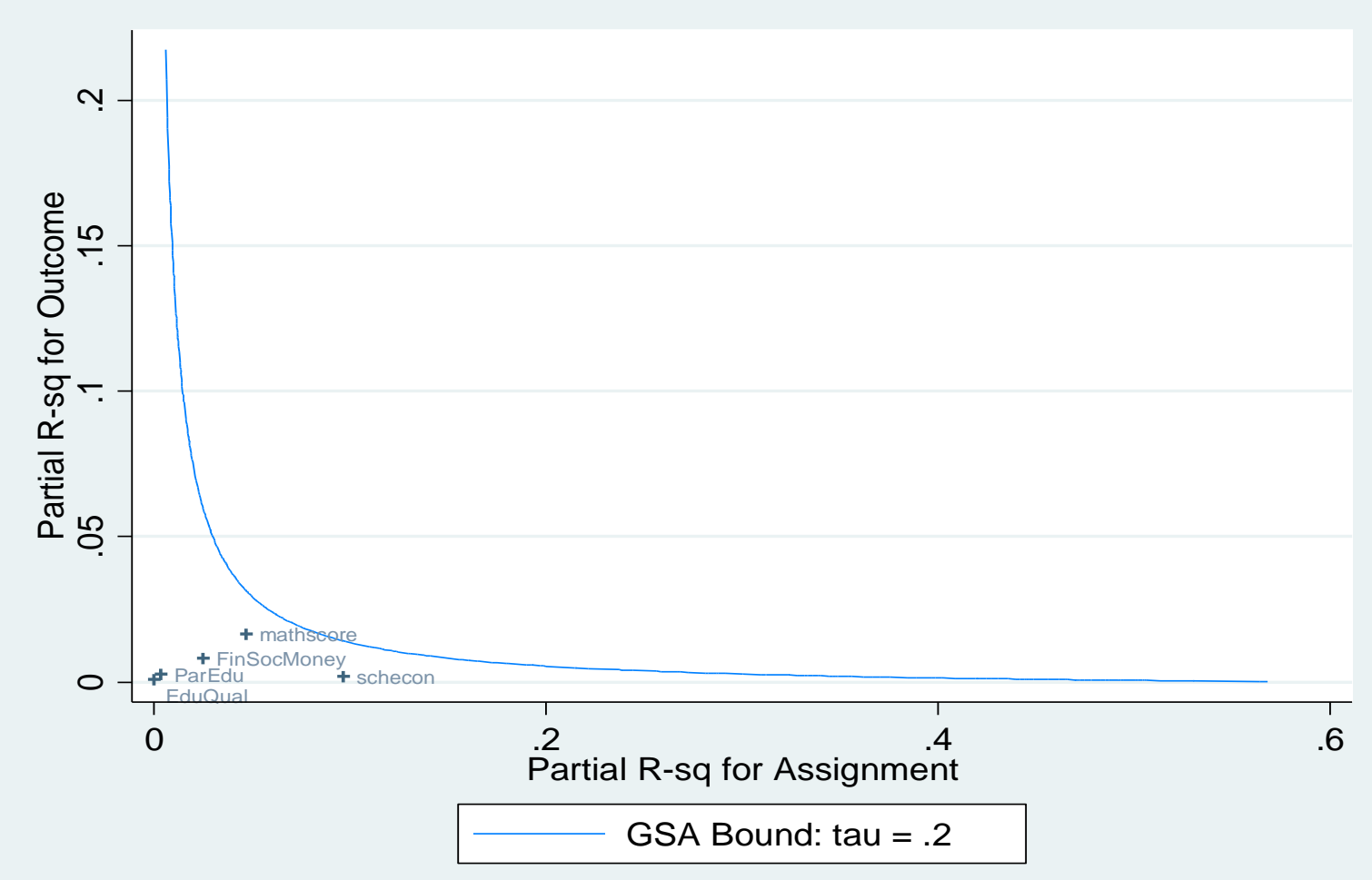

Panel A: Financial Socialization by parents on financial literacy

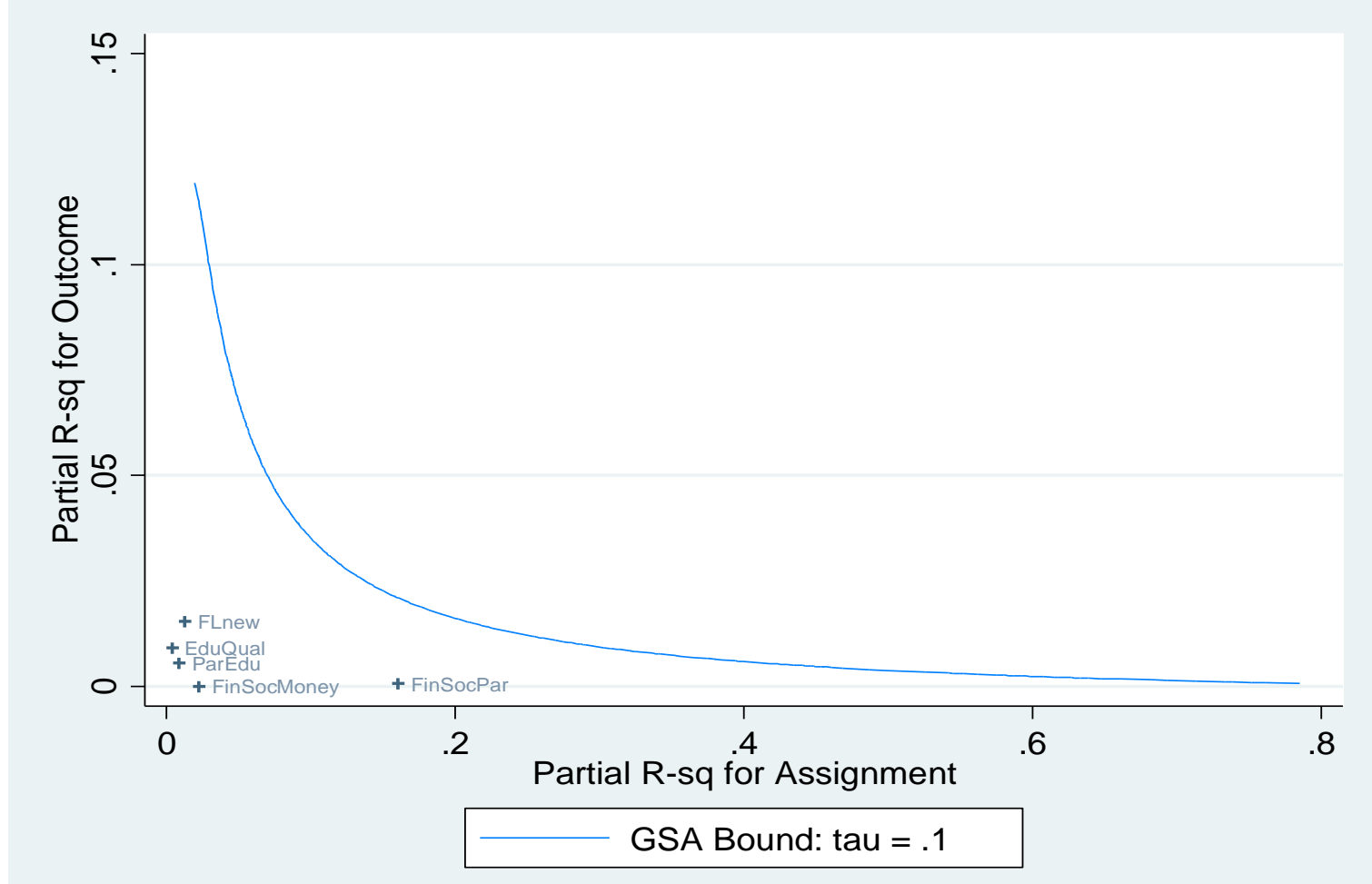

Panel B: Economics at school on diversification 


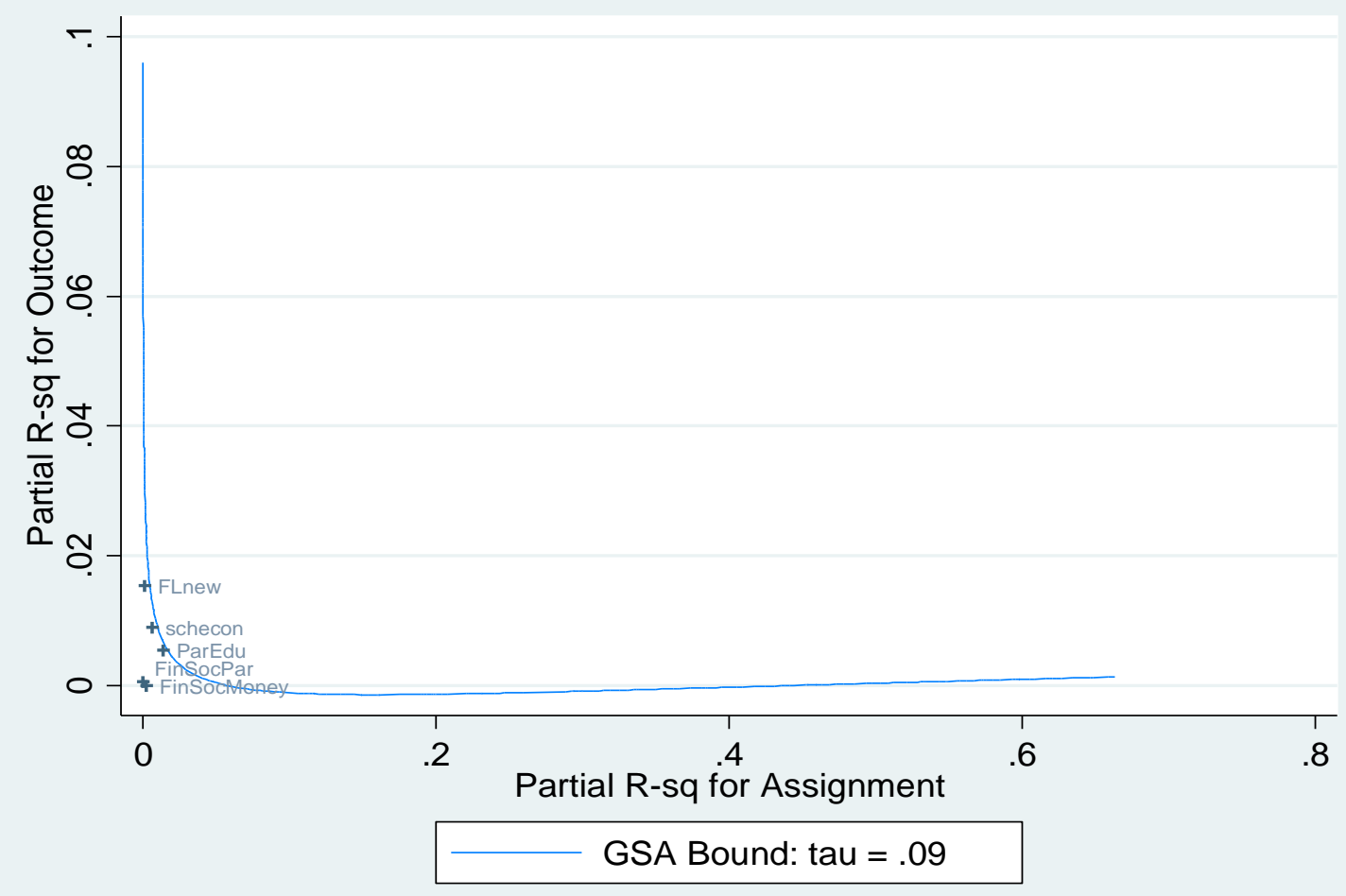

Panel C: Educational quality on diversification 